\title{
Large-scale Climate Change Vulnerability Assessment of Stream Health
}

2

3

4

5

6

7

8

9

10

11

12

13

14

15

16

17

0

${ }^{\mathrm{b}}$ Department of Geography, Michigan State University, East Lansing, MI, United States

${ }^{\mathrm{c}}$ International Joint Commission, Great Lakes Office, Windsor, ON N9A 6T3, Canada

*Corresponding Author: A. Pouyan Nejadhashemi, 524 S. Shaw Lane, Room 225, Department of Biosystems and Agricultural Engineering, Michigan State University, East Lansing, MI, 48824, USA. Phone: (517) 432-7653, Fax:

(517) 432-2892, Email: pouyan@msu.edu

1

2

3

4

5

\footnotetext{
${ }^{a}$ Department of Biosystems and Agricultural Engineering, Michigan State University, East Lansing, MI, United
} States 
ABSTRACT

Freshwater streams are critical resources that provide multiple benefits to humans and

22

23

24

25

26

27 aquatic biota alike. As climate changes, it is projected that changes to the hydrological cycle and water temperatures will affect individual biota and aquatic ecosystems as a whole. The goal of this study was to determine the extent of climate change impacts on stream ecosystems as represented by four commonly used stream health indicators (Ephemeroptera, Plecoptera, and Trichoptera taxa (EPT), Family Index of Biotic Integrity (FIBI), Hilsenhoff Biotic Index (HBI), and fish Index of Biotic Integrity (IBI)). Seven watersheds in Michigan were selected based on stream thermal regimes. The Soil and Water Assessment Tool was used to simulate streamflow and pollutant loads. Important variables for each thermal class were selected using a Bayesian variable selection method and used as inputs to adaptive neuro-fuzzy inference systems models of EPT, FIBI, HBI, and IBI. Finally, an ensemble of climate models from the Coupled Model Intercomparison Project Phase 5 were used to determine the impacts of climate on the stream health in 2020-2040 compared to 1980-2000. The risk of declining stream health was determined using cumulative distribution functions. A stream temperature regression model was also developed to assess potential changes in stream thermal regimes, which could cause shifts in composition of aquatic communities. Several flow regime variables, including those related to flow variability, duration of extreme events, and timing were mainly affected by changing climate. At the watershed scale, most indicators were relatively insensitive to changing climate and the magnitude of stream health decline was low. However, at the reach scale, there are many instances of high risk and large magnitude of declines in the stream health indicators. At the 
41 same time, several streams experienced changes in thermal class, mostly transitioning from cold-

42 transitional and cool streams to warm streams. This research demonstrated the applicability of

43 the stream health modeling process in performing a climate change impacts assessment.

44 Keywords: Stream Health; Biological Integrity; Fish; Macroinvertebrate; Fuzzy Logic; Stream

45 Temperature 


\section{$47 \quad 1$ INTRODUCTION}

Since 1951, the Earth's surface has warmed by $0.72{ }^{\circ} \mathrm{C}$, while the last three decades were

49 successively warmer than any ever recorded (IPCC, 2013). The Intergovernmental Panel on

50 Climate Change (IPCC) concluded that it is extremely likely that anthropogenic activities,

51 primarily greenhouse gas (GHG) emissions, caused more than half of these increases (IPCC,

52 2013). By the end of the $21^{\text {st }}$ century, increases in global average surface temperatures

53 projections from the Coupled Model Intercomparison Project Phase 5 (CMIP5) simulations are

54 projected to be between $0.3-4.8^{\circ} \mathrm{C}$ depending on radiative forcing, although these increases will

55 vary regionally (IPCC, 2013). As the atmosphere warms, its water holding capacity will increase

56 and the hydrologic cycle will intensify, resulting in changes in frequency of precipitation

57 extremes and increased evaporation and dry periods (Liebowitz et al., 2014; Piani et al., 2010;

58 Praskievicz and Bartlein, 2014; Prudhomme et al., 2014). These changes in the hydrologic cycle

59 have potentially serious implications for water resources and freshwater ecosystems. Hydrologic

60 conditions such as floods and droughts have direct ecological effects (Lytle and Poff, 2004),

61 while water temperature is a controlling factor on species distribution and community

62 composition (Durance and Omerod, 2007; DeWeber and Wagner, 2014). Some locations have

63 already experienced shifts in aquatic community composition and structure towards selection of

64 species that tolerate increased temperature and lower flows (Chessman, 2009). The IPCC (2014)

65 has recognized that climate change is a significant threat to global biodiversity and ecosystem

66 function. 
Biological assessments are a commonly used tool to assess the health of freshwater ecosystems. Biological assessments measure an aquatic ecosystem's biological integrity and the effects of stressors on that ecosystem's biota (USEPA, 2011). Here, the biological integrity of an ecosystem is based on its ability to "support and maintain a balanced, integrated, and adaptive community of organisms with a species composition, diversity, and functional organization" that is similar to that region's natural habitat (Karr, 1987). Multimetric biological indices or biotic indicators are a commonly accepted method for measuring ecosystem health and response to stressors (Einheuser et al., 2012). They measure ecosystem quality by communicating severity and extent of impairment through establishing a gradient of biological condition (Karr and Yoder, 2004). For example, the fish Index of Biotic Integrity (IBI) consists of metrics that describe structure, composition, and functional organization of a fish community (Lyons et al., 1996). In addition to fish, macroinvertebrates are prominently used in biological assessments because they respond quickly to a multitude of stressors at local scales (Flinders et al., 2008; Herman and Nejadhashemi, 2015). Using several biotic indicators is beneficial because it provides a holistic assessment of ecosystem health (Clapcott et al., 2012).

Community-level biological assessment is critical in light of potential climate change (Woodward et al., 2010). Most studies linking climate change and aquatic ecosystems have focused on individual species and taxonomic groups rather than communities (Lawrence et al., 2010; Woodward et al., 2010) such as individual macroinvertebrates (Domisch et al., 2011) and salmonids (Rahel et al., 1996; McDaniels et al., 2010; Isaak et al., 2012). Meanwhile, there are concerns that existing biotic indices ignore the potential effects of a changing climate and may become obsolete (Woodward et al., 2010). However, studies in Europe (Leunda et al., 2009) and North America (Larwrence et al., 2010) determined that biotic indicators were robust in response 
90 to a changing climate, establishing their continued utility in biological assessment. In addition,

91 Lawrence et al. (2010) demonstrated that higher taxonomic resolutions (order and family) rather

92 than genus and species were useful for detecting climate change.

93 Climate change impacts assessments that focus on individual species responses are

94 invaluable, but natural resources managers are often interested in the broader system view that

95 biological assessments provide. At the same time, our knowledge of ecological conditions at

96 large scales is limited by incomplete monitoring data (Wang et al., 2008; Einheuser et al., 2012).

97 Therefore, the goal of this research is to focus on the impacts of climate change on broader

98 ecosystems health. By developing biotic indicator models of fish and macroinvertebrates, we can

99 establish a system-level outlook of potential changes in stream health.

\section{MATERIALS AND METHODS}

\section{$101 \quad 2.1 \quad$ Study Watersheds}

Seven 8-digit hydrologic unit code (HUC-8) watersheds in Michigan, USA were the

103 subject of this study: the Au Sable (HUC 04070007), Boardman-Charlevoix (HUC 04060105),

104 Cedar-Ford (HUC 04030109), Flint (04080204), Muskegon (04060102), Pere Marquette-White

105 (04060101), and Raisin (04100002) (Figure 1). The watersheds were selected based on their

106 availability of fish and macroinvertebrate sampling data, and diversity of physiographic

107 characteristics including land use, soils, and stream thermal classes.

Figure 1. 
111 Charlevoix, and Cedar-Ford primarily consist of forests and wetlands, while the Flint, Raisin,

112 Muskegon, and Pere Marquette-White are a mix of agriculture, forests, urban areas, and

113 wetlands. Soils range from well-drained sandy soils for the Au Sable, Boardman-Charlevoix,

114 Muskegon, and Pere-Marquette White to more poorly drained soils in the Flint and Raisin

115 watersheds.

The Au Sable River watershed surface geology consists of coarse-textured sands and 117 gravels from glacial and ice-contact outwash (Zorn and Sendek, 2001). Over 90\% of the

118 watershed consists of sand, loamy-sand, or wet-sandy-organic (Zorn and Sendek, 2001). The

119 sandy soils are poorly consolidated and susceptible to erosion. Soil and geologic conditions in

120 the watershed cause high groundwater inflows and very stable streamflow (Zorn and Sendek,

121 2001). Almost $90 \%$ of the stream length in the watershed is composed of headwater streams

122 (Strahler stream order 1-3), while the remaining is order 4-6, where order 6 makes up 6\% of total

123 watershed stream length $(152 \mathrm{~km})$.

The Boardman-Charlevoix watershed consists of similar surficial geology and soils,

125 where glacial till and outwash dominate. Soils are primarily dry and sandy of the Kalkaska,

126 Grayling, and Rubicon series (Kalish and Tonello, 2014). However, the fruit-growing areas of

127 the watershed are characterized by poorly drained organic soils such as Tawas and Carbondale

128 (Kalish and Tonello, 2014). Flows in the Boardman watershed and tributaries are very stable due

129 the geology and soils. Hydrologic conditions in the Boardman-Charlevoix are similar to the Au

130 Sable, given their similar geology, soils, and geographic proximity. Over $90 \%$ of the watershed

131 is composed of headwater streams, while 5 is the highest stream order present. 
The Cedar-Ford watershed surficial geology is primarily made of medium-textured

133 glacial till. Alfisols and histosols are the dominant soil types, alternating between well drained and poorly drained conditions. Slopes in the watershed are moderate, averaging between 1-7\%. Streamflow in the watershed is moderately stable. The Cedar-Ford watershed has the smallest stream orders of the study watersheds: $86 \%$ of the stream length is order $1-3$, with the remaining $14 \%$ being 4 th order streams.

The Flint River watershed geology and soils vary widely from the headwaters to the outlet.The headwaters are generally comprised of rolling hills with sandy loam glacial moraines, while the downstream reaches and main branch of the Flint River flatten out into a glacial lake plain with poorly drained clay and sandy soils (Leonardi and Gruhn, 2001). Alterations in the Flint River watershed (e.g. urbanization and agricultural expansion) have led to unstable daily flows that are highly responsive to storms and snowmelt. The Flint River is the only river in the study watersheds to reach order 7 (for $8 \mathrm{~km}$ of its length). Almost $90 \%$ of the total watershed stream length is comprised of headwater streams, while the remaining streams are generally of order 4-5.

The Muskegon River watershed is dominated by glacial landforms that support constant groundwater inputs (O’Neal, 1997). Soils in the watershed are primarily classified as moderately and highly permeable. Glacial aquifers composed of lacustrine sand, till, and outwash and glaciofluvial deposits underly the entire watershed (O’Neal, 1997). Daily streamflow for the Muskegon River and its tributaries are moderately stable with high levels of groundwater input (O’Neal, 1997). Stream orders in the Muskegon are 90\% headwaters, and 10\% mid-reaches. The Muskegon River itself is order 6 for 171 stream $\mathrm{km}$. 
The Pere Marquette-White watershed geology is primarily glacial drift, with both high

155

moraines and low outwash plains (Balke et al., 2011). Overlying soils are sandy with moderate to excessive drainage. Some hydric soils are present (mucky sand and muck) and form wetland complexes in the headwaters of the watershed (Balke et al., 2011). Topography in the watershed is generally flat. Given the surface geology and soils, streams in the Pere Marquette-White watershed are generally groundwater fed and moderately stable (Balke et al., 2011). Stream orders in the Pere Marquette-White are $87 \%$ order $1-3$ and $13 \%$ order $4-6$, where over half of the total stream miles are 1 st order streams.

The River Raisin watershed is comprised of undulating and hilly topography in the west and northwest leading into flat terrain in the southeast (Dodge, 1998). In the northwestern glacial moraines (headwaters) the geology and soils are permeable and semi-permeable, leading to relatively stable flows and more groundwater recharge (Dodge, 1998). In the flat southeast lake plain, the surficial geology and soils are less permeable with flashy streams (Dodge, 1998). In general, agricultural expansion and channel modification have made streamflow throughout the watershed flashier. The River Raisin watershed contains $85 \% 1-3$ order streams and 15\% order 4-6 streams.

Stream thermal class was used as a selection criteria because temperature dictates the abundance, occurrence, distribution, and physiology of aquatic biota (Lyons et al., 2009; Poole and Berman, 2001; Wehrly et al., 2003). Differences in water temperature among streams are most pronounced during peak summer temperatures in the northern hemisphere (Caissie et al., 2006; Wehrly et al., 2009). Therefore, July mean temperature is a commonly used predictor of fish assemblage structure (Steen et al., 2008; Werhly et al., 2003; Wehrly et al., 2009). Given the importance of temperature as a control of stream ecosystem function (Olden and Naiman, 2010), 
177 Zorn et al. (2008) developed stream thermal classes (cold, cold-transitional, cool, and warm) for

178 Michigan based on July mean water temperature and fish communities. Macroinvertebrates are

179 also affected by stream temperature, as modified thermal regimes can disrupt emergence and

180 reduce population success (Bunn and Arthington, 2002). However, because of the economic

181 value of fisheries and its management need, stream thermal classes have only been developed

182 based on fish in Michigan. Study watersheds and stream thermal classes are presented in Figure

183 1. The stream thermal classes and watersheds that have at least $10 \%$ of streams in a particular

184 class are defined in Table 1.

Table 1.

186

\subsection{Data Collection}

\subsubsection{Physiographic Data}

Several physiographic datasets were used for watershed model development, including

topography, land use, soils, stream networks, and climate. The topography dataset was the $30 \mathrm{~m}$

190 resolution United States Geological Survey (USGS) gridded National Elevation Dataset (NED,

191 2014). The land use dataset was the 30m United States Department of Agriculture (USDA) -

192 National Agricultural Statistics Service (NASS) 2012 Cropland Data Layer (NASS, 2012). The

193 soil dataset was the spatial and tabular USDA Soil Survey Geographic Database (SSURGO) with

194 resolutions ranging from 1:12,000 to 1:63,600. Stream networks were obtained from the Great

195 Lakes Regional River Database Classification System developed by the Michigan Institute of

196 Fisheries Research (IFR), based on the 1:24,000 resolution National Hydrography Dataset Plus

197 (NHDPlus). These streams and catchments are defined so each individual stream segment and

198 subwatershed represents a homogeneous area of biological, physiographical, and 
geomorphological characteristics (Einheuser et al., 2013b). Daily precipitation and air temperature (maximum and minimum) were obtained for 1978-2005 from the National Climatic

Data Center (NCDC, 2015). The NCDC dataset was comprised of 40 precipitation and 39 temperature stations selected for minimal missing data (less than 5\% missing of the 1978-2005 record). Precipitation and temperature station locations are presented in Figure A1 of the Supplementary Materials.

\subsubsection{Biological Data}

Fish data were from the Michigan stream fish survey database managed by the Institute for Fisheries Research (Ann Arbor, Michigan). This database contains survey records where wadeable stream fish were collected using backpack and tow-barge electrofishing units from May to October between 1982 and 2008 (Wang et al. 2012). Macroinvertebrate data were from the Michigan Department of Environmental Quality. This database contains survey records that macroinvertebrates were sampled using dip-nets on multiple habitats from June to September in of 1996-2003 (MDEQ, 1997). From these data, we calculated three macroinvertebrate and one fish indicator: number of Ephemeroptera, Plecoptera, and Trichoptera (EPT) taxa, Family-level Index of Biotic Integrity (FIBI), the Hilsenhoff Biotic Index (HBI), and the fish Index of Biotic Integrity (IBI). Both fish and macroinvertebrate data were used because they respond differently to stressors, operate on dissimilar scales, and represent unique trophic levels (Barbour et al., 1999; Flinders et al., 2008). The total number of samples in each stream thermal class varied: 141 macroinvertebrate and 85 fish for cold, 51 macroinvertebrate and 38 fish for coldtransitional, 120 macroinvertebrate and 113 fish for cool and 123 macroinvertebrate and 59 fish for warm. 
EPT is a presence count of pollutant-intolerant macroinvertebrate taxa, where lower

222 counts indicate potential aquatic community degradation. The FIBI is a multi-metric index

223 comprised of family-level macroinvertebrate community composition and richness metrics, with

224 a score ranging from 0-45 (45 is excellent). The HBI (Hilsenhoff, 1988) is an organic pollution

225 tolerance index for macroinvertebrates that ranges from 0 (excellent) to 10 (very poor). The fish

226 IBI is a multi-metric index composed of community measures of richness, composition, and

227 abundance (Wang et al., 2007); it ranges from 0 (very poor) to 100 (excellent).

\subsection{Modeling Process}

The modeling process contains two primary procedures: development of stream health models and development of the stream temperature model (Figure 2). Both procedures began

231 with baseline climate data and climate scenarios from climate models' future projections of

232 temperature and precipitation. The stream health models began with development of Soil and

233 Water Assessment Tool (SWAT) watershed models that simulate streamflow and water quality

234 for each study stream. Ecologically relevant flow regime variables were calculated using the

235 Hydrologic Index Tool (HIT) on SWAT streamflow output. Bayesian variable selection

236 (Woznicki et al., 2015) identified best variable sets for use as predictors in stream health models

237 of EPT taxa, FIBI, HBI, and IBI. These models were developed for each thermal class.

238 Meanwhile, the statistical stream temperature model used climate and physiographic data to 239 predict future stream temperatures and potential changes in thermal class. 


\subsection{Development of Ecologically-Relevant In-Stream Variables}

242

243

244

245

246

247

248

249

250

251

252 253 subwatersheds.

254

255

256

257

258

259

260

261

Development of ecologically relevant in-stream variables consists of two components: the watershed model (SWAT) and the flow regime characterization using the HIT. SWAT (Arnold et al., 1998) was developed for the USDA - Agricultural Research Service to predict the impact of land management practices on water, sediment, and chemical yields in large watersheds (Neitsch et al., 2005). The model is physically based, semi-distributed, and allows for simulation over long time periods (Neitsch et al., 2005). SWAT simulates hydrology, plant growth, evapotranspiration, sediment routing, and nutrient cycling. SWAT is semi-distributed, where a watershed is delineated into spatially oriented subwatersheds that are further delineated into non-spatial hydrologic response units (HRUs). Each individual HRU consists of a homogeneous land use, soil type, slope, and land management practice. In this study, each subwatershed contained only one HRU due to the characteristics of the IFR streams and

Each watershed model was calibrated and validated for streamflow, sediment, total nitrogen (TN), and total phosphorus (TP). Continuous daily streamflow data was obtained from USGS gauging stations and grab samples of sediment and nutrients were obtained from the Michigan Department of Environmental Quality (MDEQ). SWAT Streamflow calibration and validation were performed from 1998-2001 and 2002-2005, respectively. Sediment and nutrient monthly load calibration and validation was performed for varying periods from 1998-2005, depending on availability of monitoring data. Details on model calibration and validation are presented in Woznicki (2015). 
263 et al., 2006) to characterize 171 ecologically relevant flow regime indices over 1980-2000. The

264 flow regime indices are comprised of the five components of the natural flow regime: magnitude

265 (M), frequency $(\mathrm{F})$, duration (D), timing $(\mathrm{T})$, and rate of change (R). Each index is also

266 characterized by flow event type: low (L), average (A), and high (H). These indices, along with

267 annual and monthly sediment, TN, and TP loads simulated by SWAT were considered as

268 potential variables (39 total) for the stream health models. In addition, drainage area and July

269 mean stream temperature were included in the process. Drainage area was included because

270 watershed size is a key predictor of aquatic biota distribution (Pont et al., 2009). This resulted in

271212 total variables for each stream in the study watersheds.

\section{$272 \quad 2.5 \quad$ Stream Health Model}

The stream health modeling process consisted of variable selection and model

274 development. Variable selection was performed using Bayesian variable selection and the stream

275 health models were developed using adaptive neuro-fuzzy inference systems (ANFIS).

The variable selection process was performed using the Bayesian variable selection

277 method presented in Woznicki et al. (2015), where it was concluded that this method is superior

278 to other selection methods such as principal component analysis and Spearman's Rank

279 Correlation. In Bayesian variable selection the final outcome is a selectivity measure that

280 describes the probability of a variable being selected out of all posterior samples. Selectivity was

281 used to identify the top three variables to be used in development of the stream health models.

282 Full selectivity results are presented in Woznicki (2015). 
Several approaches have been commonly used to model ecological systems, but fuzzy

284

logic is often used due to its ability to model these complex, nonlinear problems (Chen and Mynett, 2003; Adriaenssens et al., 2004; Marchini et al., 2009; Einheuser et al., 2013). Adaptive neuro fuzzy inference system (ANFIS) (Jang, 1993), a fusion of artificial neural networks (ANNs) and fuzzy logic, was used to develop the stream health models for each combination of stream health indicator (EPT, FIBI, HBI, and IBI) and stream thermal class (cold, coldtransitional, cool, and warm). Fuzzy logic is a soft-computing technique that maps the degree of membership of a value to a fuzzy set, where 0 indicates no membership and 1 indicates full membership. These are defined by graphical membership functions (MFs) defined by particular shapes. If-then inference rules determine a value's membership to each specific function. While fuzzy logic is proficient in modeling ecological systems (Chen and Mynett, 2003), development of MFs and if-then statements is time consuming, intensive, and subjective (Adriaenssens et al., 2004). ANFIS is useful in this respect, because it uses ANNs to build and optimize MFs through minimizing predictive error in a validation dataset (Jang, 1993).

The MATLAB (R2013b) Fuzzy Logic Toolbox was used to build the ANFIS models. Five MF shapes were tested: triangular, trapezoidal, Gaussian, Gaussian composite, and generalized bell. A limit of three variables was placed on model development, because increasing the number of variables requires an increase in the number of fuzzy parameters, and subsequently more input data, which was scarce. To prevent over-fitting, the number of ANFIS parameters should not exceed the number of training input (Sanikhani and Kisi, 2012). For the same reason, a maximum of four MFs per variable was used. All possible combinations of MF shape, number of MFs, and variables (selected from the Bayesian method) were fit (over 500 epochs) using 10-fold cross validation. More details about the ANFIS model details can be found 
306 in Woznicki (2015). Model performance ranged from $R^{2}$ equal to 0.49 (cold) to 0.68 (cold-

307 transitional) for EPT, 0.44 (cool) to 0.74 (cold-transitional) for FIBI, 0.41 (cold) to 0.65 (cold-

308 transitional) for HBI, and 0.37 (cool) to 0.90 (cold) for IBI. The most commonly selected MF

309 shapes were nonlinear: Gaussian, Gaussian composite, and generalized bell. The selected

310 variables for the final 16 stream health models are presented in Table 2.

Stream health scores were analyzed at the reach level and the stream thermal class level.

312 Overall stream health scores at the thermal class level were calculated using length-weighted

313 averages. Here, the stream health score for each individual reach was multiplied by its length.

314 These values were summed for each thermal class and divided by the total reach length in each

315 thermal class.

Table 2.

\subsection{Climate Change Data}

The control period of 1980-2000 was compared with future climate change data that was

319 obtained from World Climate Programme's CMIP5 (Taylor et al., 2011) multi-model ensemble

320 for 2020-2040. The 2020-2040 period was selected for analysis because near-century changes

321 are more applicable to decision-makers. Middle and end of century climate change is construed

322 in terms that are more abstract by decision-makers (Weber, 2006). This will affect the perceived

323 risk of declining stream health and damage the potential for development of adaptation strategies

324 because it will require immediate costs and sacrifices to achieve distant and abstract goals

325 (Weber, 2006).

The CMIP5 dataset used in this study included simulations from ten modeling groups

327 (Table 3) comprised of sixteen general circulation model (GCMs) under three representative 
concentration pathways (RCPs), for a total of 48 scenarios. The RCPs were developed by Moss et al. (2010) for the IPCC Fifth Assessment Report and are defined by radiative forcing pathways rather than the socioeconomic scenarios and GHG emissions as in the Special Report on Emissions Scenarios (Nakicenovic and Swart, 2000) of the IPCC Third and Fourth Assessment Reports. The three RCPs used were RCP4.5, RCP6.0, and RCP8.5, where each number represents the estimated trajectory of radiative forcing $(\mathrm{W} / \mathrm{m} 2)$ by 2100 . Estimated $\mathrm{CO} \neg 2$ equivalent GHG emissions by 2100 of each RCP are approximately 650 ppm, 850 ppm, and greater than 1370 ppm for RCP4.5, RCP6.0, and RCP8.5, respectively. The CO2 concentrations used in SWAT were selected for the middle of the simulation period (2030), characterized by atmospheric concentrations of $435 \mathrm{ppm}, 428 \mathrm{ppm}$, and $448 \mathrm{ppm}$ for RCP4.5, RCP6.0, and RCP8.5, respectively.

Table 3 .

The change factor approach was used in this study to generate daily time series climate change projections. This method calculates monthly anomalies between the GCM simulated control (1980-2000) and future scenario runs (2020-2040) that are superimposed on the observed time series data (1980-2000) (Teutschbein and Seibert, 2012). Precipitation change factors are calculated using a ratio (because precipitation is zero-bounded), where a change factor of one indicates no change in precipitation. Temperature change factors are additive. Gridded GCM data was extracted at the nearest land grid point for each observation station (40 precipitation and 39 temperature) and monthly change factors were applied to the daily precipitation and daily maximum and minimum temperature. Change factors for precipitation and maximum and minimum temperature are presented in Figure 3 for one weather station central to the study 
350

351

352

watersheds (USC00203429 at $43.2025^{\circ},-85.2422^{\circ}$ in Figure A1 of the Supplementary Materials).

\section{Figure 3.}

The assumptions of the change factor method include: (1) GCMs are better at simulating relative changes rather than absolute values (Fowler et al., 2007); (2) GCM biases are similar in the control and future simulation periods (Boyer et al., 2010); and (3) the variability between the current and future climate remains the same, where bias in distribution and frequencies of simulated variables is ignored (Winkler et al., 2011; Gädeke et al., 2014). However, the change factor methodology is advantageous because it is stable and robust, widely used in hydrology (Abbaspour et al., 2009; Boyer et al., 2010; Elsner et al., 2010; Prudhomme et al., 2010; Bae et al., 2011; Bastolaet al., 2011; Chen et al., 2012; Fiseha et al., 2014; Gädeke et al., 2014), and can be used to rapidly develop a large ensemble of GCMs and emissions scenarios (Boyer et al., 2010). In addition, it assesses the uncertainty in mean GCM projected climate change, which is larger than that of the selected downscaling method (Boé et al., 2009; Chiew et al., 2009).

\subsection{Stream Temperature Model}

A stream temperature model was developed to determine if climate change would alter thermal classes, such as moving from a cold stream to a cold-transitional or cool stream. This would lead to changes in community composition and assemblage structure. When streams change thermal class, their stream health will likely be minimized because they will no longer be able to support their natural aquatic communities. The methods used were based on the July mean stream temperature models developed by Wehrly et al. (2009). A total of 332 summer stream temperature measurement sites throughout Michigan were included in the study, collected 
372 from 1990-2003 by the Michigan Department of Natural Resources (Wehrly et al., 2009). There

373 were 422 samples, with multiple years of data from some sites.

Variables were defined by either local catchment (subwatershed) or network catchment.

375 A local catchment drains directly to its corresponding stream segment, while a network

376 catchment includes all upstream areas that drain to the stream segment by land or through a

377 waterway. The six variables identified for model development by Wehrly et al. (2009) were

$378 \quad \mathrm{AREA}\left(\log _{e}\right.$ of the network catchment surface area), FOREST (percent forested land in the local

379 catchment), JULAIR (July mean air temperature), PERM (mean network catchment soil

380 permeability), SLOPE (mean network catchment slope), and WATER (percent water in the

381 network catchment). Streams and catchments (AREA) were obtained from the NHDPlus

382 (NHDPlus, 2015). Land use (FOREST and WATER) and topography (SLOPE) data were

383 obtained from the 2012 CDL and the NED, respectively. Soil data used to identify catchment

384 permeability (PERM) was obtained from the Natural Resources Conservation Service (NRCS)

385 Digital General Soil Map of the United States, STATSGO2 (NRCS, 2015) at a 1:250,000

386 resolution. Gridded July mean air temperature (JULAIR) at a $4 \mathrm{~km}$ resolution was obtained from

387 the Parameter-elevation Relationships on Independent Slopes Model (PRISM) Climate Group

388 (PRISM, 2015).

Linear mixed modeling using low-rank radial smoothing splines (LMM-Smooth) was

390 used to develop the stream temperature model. Wehrly et al. (2009) found that the LMM-Smooth

391 method outperformed multiple linear regression, generalized additive modeling, and kriging in

392 predicting July mean stream temperature for Michigan and Wisconsin. The landscape variables

393 are fixed effects, while the random error is comprised of smooth-scale and micro-scale variation

394 in stream temperature and white noise measurement error. Spatial autocorrelation in stream 
395 temperature is considered by placing knots throughout the study area that are based on the 396 distances between streams and knots (Wehrly et al., 2009). Because the method is low-rank, the 397 number of knots is less than the number of observations (Schabenberger, 2005). The $k d$-tree 398 method was used to determine optimal number and placement of knots (Schabenberger, 2005), 399 produced a total of 47 knots throughout the study area. The LMM-Smooth model was fit using 400 the SAS 9.3 GLIMMIX procedure (SAS, 2015). The LMM-Smooth model fitting process used 10-fold cross validation and the root402 mean-square error (RMSE) and mean absolute error (MAE) of each validation fold were used to 403 assess model accuracy. Average RMSE and MAE across the ten validation folds were $2.07^{\circ} \mathrm{C}$ 404 and $1.59^{\circ} \mathrm{C}$, respectively, similar in performance to the Michigan $\left(\mathrm{RMSE}=2.00{ }^{\circ} \mathrm{C}, \mathrm{MAE}=\right.$ $\left.4051.55{ }^{\circ} \mathrm{C}\right)$ and Wisconsin $\left(\mathrm{RMSE}=2.32{ }^{\circ} \mathrm{C}, \mathrm{MAE}=1.83{ }^{\circ} \mathrm{C}\right)$ LMM-Smooth models fit by 406 Wehrly et al. (2009). The standardized coefficients of the fixed effects for the LMM-Smooth 407 model fit to the full dataset are presented in Table A2 of the Supplementary Materials. All 408 variables were significant at $\alpha=0.01$ except FOREST, which also was the case for the Wisconsin 409 model developed by Wehrly et al. (2009). Following model fitting, each of the 10 -fold models 410 were applied to all streams in the study area for each climate scenario to develop projections of 411 changes in future stream temperatures based on the predictions of the ten models. The stream 412 temperature projections were based on the change factors applied to the NCDC station data with 413 results representing average July mean stream temperature for 2020-2040. 


\section{RESULTS AND DISCUSSION}

\section{$415 \quad 3.1$ Ecological-Relevant Variables and Stream Health}

416

417

418

419

420

421

422

423

424

425

426

427

428

429

430

431

432

433

434

435

Scatterplots of stream health indicators versus percent changes under climate change scenarios for predictor variables used in the stream health models are presented in Figure 4 (cold) and Figure A2 (cold-transitional), Figure A3 (cool), and Figure A4 (warm) of the Supplementary Materials. Here, the stream health predictions and predictor variable values were calculated using the stream length-weighted average across all study streams. Each figure also presents the Spearman's rank correlation coefficient $(\rho)$ between stream health measures and percent change in flow regime variable. These figures demonstrate potentially altered flow regimes in the future (comparing 2020-2040 to the baseline 1980-2000), and that these changes both positively and negatively affect stream health represented by EPT, FIBI, HBI, and IBI.

Several of the stream health indicators were correlated with changes in predictor variables, indicated by a larger $r$. For example, the projected changes in variability of monthly flow values MA31 (August flows) and MA27 (April flows) were highly correlated with EPT and HBI, respectively (Figure 4). This shows that when variability decreased, stream health improved in cold streams. Note that HBI was positively correlated with increasing variability; this indicates that stream health declined with increased flow variability because lower HBI represents better stream health. These correlations are likely due to relatively lower flashiness in cold streams (especially in the Boardman-Charlevoix and Au Sable) because they are primarily groundwater-fed rather than surface-fed (Zorn and Sendek, 2001). However, projected increases in timing variables TA1 (constancy) and TA2 (predictability) result in declining FIBI, although the increases in constancy and predictability and decrease FIBI were relatively minor. 
Figure 4.

Several input variables were correlated with stream health indices used in the coldtransitional models (Figure A2 in the Supplementary Materials). As with cold streams, lower

439 flashiness and improved predictability resulted in improved stream health measures. Increases in 440 TH3 (seasonal predictability of non-flooding) improved EPT, demonstrating the importance of 441 predictability in the timing of flood free periods for macroinvertebrates; with the potential for 442 increases in future flooding and variability in flood timing due to climate change, sensitive EPT 443 taxa will decline. Decreases in skewness of monthly flows (MA40) resulted in lower FIBI, while 444 increasing RA9 (variability in number of days where the change in flow from one day to another 445 changes direction), caused falling FIBI. The changes in variability as represented by MA40 and 446 RA9 demonstrate the importance of consistent flows (less flashiness) for cold-transitional 447 streams. Finally, fish IBI decreased with greater RA7 (negative changes in flow from previous 448 day's flow) magnitudes, where the greater the average decrease in flow from the previous day 449 resulted in worse stream health.

Predictor variables for cool streams (Figure A3 in the Supplementary Materials)

451 experienced trends as with cold and cold-transitional streams. As climate change increased 452 variation in February flows (MA25), both EPT and FIBI decrease; a similar relationship was 453 found in the colder thermal classes. In addition, TH3 (seasonal predictability of non-flooding) 454 was positively correlated with FIBI, as in cold and cold-transitional streams. Changes in low 455 (DL) and high (DH) duration variables with respect to HBI also exhibited clear trends. When 456 climate changes projected increases in DL15 (magnitude of 90\% exceedance flows), stream 457 health improved, while greater high flow durations (DH18) negatively affected stream health. 458 This demonstrates the balance between the benefits of greater low flows but highlights potential 
459 impacts on stream health as duration of flooding events increases. No obvious trends were 460 present with IBI variables, although decreases in constancy (TA1) and predictability (TA2)

461 resulted in slight IBI declines. Due to the overall small decreases in IBI coupled with small 462 changes in TA1 and TA2, overall cool IBI can be considered insensitive to climate change.

Warm stream predictor variables' characteristics were similar to some of those found in 464 cool streams (Figure A4 in the Supplementary Materials). For example, DH22 (number of days 465 between flood events with recurrence interval of 1.67 years) increased in most climate scenarios, 466 resulting in improved fish IBI. This demonstrates that more frequent flooding as projected in 467 some climate scenarios will be detrimental to stream health. However, many of the variables 468 experienced slight increases in flow variability due to climate change (DL9, FH2, DL17, and 469 MH19). Most warm streams in the study area are located in watersheds that contain flow regimes 470 driven by surface runoff (due to relatively poorly drained soils and extensive agricultural 471 operations). Increases in DL9 (variability annual minimum of 30-day moving average flow),

472 FH2 (variability in high pulse count), DL17 (variability in low pulse duration), and MH19

473 (skewness in annual maximum flows) improved stream health overall. Because the increases in 474 variability are not extreme under climate change, they maintain the existing flow regime of 475 surface runoff-driven streams, and their increases are beneficial to macroinvertebrate and fish 476 communities in warm streams. Overall, climate change affects flow regime of streams in all thermal classes. However, 478 these changes were projected to have both positive and negative effects on stream health. The 479 changes in EPT, FIBI, and HBI with respect to changes in the predictor variables were relatively 480 low, indicating that coldwater macroinvertebrates are somewhat insensitive to changing climate. 481 Changes in cold fish IBI were much greater. The resulting impacts on macroinvertebrate and fish 
482 communities demonstrate the contrast between stream thermal classes and their biotic response

483 to climate change. Healthy biotic communities in cold and cold-transitional streams will be

484 contingent upon continued predictability and low flashiness of representative streams, while

485 warm streams showed the importance of maintaining a surface runoff-driven flow regime to

486 stream biota. Meanwhile, the transitional nature of cool streams was a bridge between the effects

487 of climate change on cold streams and warm streams by exhibiting similarities to both thermal

488 classes.

\section{$489 \quad 3.2 \quad$ Climate Change Impacts on Stream Temperature}

490

491

492

493

494

495

496

497

498 499 do not normally reside in that environment.

500

501

502

Understanding potential alterations in stream thermal class under climate change is also critical for the development of adaptation strategies. Where the thermal characteristics of a stream are projected to become warmer (e.g. cold streams transitioning to cool or warm), there is the potential for shifts in the characteristics of fish and macroinvertebrate communities. The stream temperature model was used to develop projections of changes in future stream temperature in 2020-2040 compared to the baseline 1980-2000. The goal was to identify streams that are at risk of changing their thermal class based on July mean stream temperature as defined by Zorn et al. (2008). If a stream thermal class is projected to change, the composition of the biota in that stream are at risk, and the stream habitat may become more suitable for species that

Changes in stream temperature were projected to be smaller than the projected changes in air temperature. Mean increases were consistent across thermal classes (with minimum and maximum in brackets): $+0.81^{\circ} \mathrm{C}\left[0.21-1.62^{\circ} \mathrm{C}\right]$ for cold streams, $+0.82^{\circ} \mathrm{C}\left[0.26-1.63^{\circ} \mathrm{C}\right]$ for 
503 cold-transitional streams, $+0.82^{\circ} \mathrm{C}\left[0.26-1.64^{\circ} \mathrm{C}\right]$ for cool streams, and $+0.82^{\circ} \mathrm{C}\left[0.29-1.67^{\circ} \mathrm{C}\right]$

504 for warm streams.

505 These changes translated into some shifts in thermal classes, where a colder class

506 converted to a warmer class. Figure 5 presents the number of stream kilometers across the study

507 area in each class change. Warm streams do not experience any change in stream class because

508 there were no climate scenarios that project cooler July mean air temperatures. The greatest

509 changes occur in the "transitional" streams, cold-transitional and cool. This was expected

510 because they are defined by relatively narrow stream temperature ranges (Table 1) and are

511 occupied by varying biota that prefer cold and cool waters. Of greatest concern was the warming

512 of cold streams due to their temperature sensitive biota. Across all climate scenarios, an average

513 of $20 \%$ of the cold streams (based on length) became cold-transitional, while no streams

514 increased by more than one thermal class. Projected changes in stream thermal class across all

515 climate scenarios are presented in Figure 6 for the Pere Marquette-White watershed. This figure

516 confirms the overall minimal changes in thermal class. Due to only a limited number of changes

517 occurring (which were shifts to cold-transitional streams), cold streams will still be able to

518 support coldwater species and negative effects would likely only be experienced by the most

519 sensitive coldwater species. This is because cold-transitional streams still support primarily

520 coldwater species (Zorn et al., 2008).

Figure 5.

Figure 6. 


\subsection{Climate Change Vulnerability Assessment of Stream Health}

524

525

526

527

528

529

530

531

532

533

534

535

536

537

538

539

540

541

542

543

544

Cumulative distribution functions (CDFs) were developed based on the stream lengthweighted average of EPT, FIBI, HBI, and IBI for each thermal class (Figure 7). In this figure, stream thermal classes are defined by row and stream health indicators are defined by column

(e.g. top-left is EPT Taxa for cold streams and bottom-right is IBI for warm streams). The CDFs represent stream health values under climate change projections (2020-2040) compared to the baseline stream health (1980-2000). Each CDF indicates the relative risk of declining stream health for each thermal class. The location of the baseline stream health on the CDF identifies the probability declining stream health under projected future climate. In addition, the slopes of the CDFs indicate the climate change sensitivity of each thermal class and stream health indicator. A greater CDF slope represents lower sensitivity of the stream health indicator to changing climate.

\section{Figure 7.}

The risk of declining in average stream health and the indicators' sensitivity to climate change varied greatly across stream indicators and thermal classes (Figure 7). For EPT, the risk of decline is relatively low (less than $50 \%$ for all thermal classes). The sensitivity of EPT to climate change is also low because there is little variation in EPT across climate scenarios. FIBI demonstrated a greater risk of decline, where all but cold-transitional streams are projected to experience greater than 50\% risk of FIBI degradation. Cold-transitional and cool streams also are the most sensitive with respect to FIBI. HBI is likely to improve overall (decreasing HBI represents better stream health, left of the current health), especially in the warmer thermal classes. Cool and warm streams' HBI was projected to improve under all climate scenarios. 
545 Finally, IBI sensitivity to climate change varied greatly across thermal class. Cold streams were 546 highly sensitive to climate change and all climate scenarios projected declines of up to 20 points. 547 Meanwhile, IBI in cold-transitional and cool streams was projected to decline, but the magnitude 548 of the decline was much less than for cold streams.

Climate sensitivity of each stream health indicator and thermal class combination is 550 largely a function of the ANFIS stream health models and the predictor variables. We can link 551 the relationship between how climate change altered the predictor variables in section 4.1 to the 552 CDFs. For example, the average timing variables TA1 (constancy) and TA2 (predictability) do 553 not experience extreme changes (Figure 4), and therefore cold-EPT is somewhat insensitive to 554 climate change (Figure 7). Meanwhile, cold-IBI is greatly declines under changing climate 555 (Figure 7), likely because of the climate sensitivity of the timing variables that were used in the 556 ANFIS stream health models. Here, variables TL1 (Julian date of annual minimum flow) and 557 TL2 (variability in Julian date of annual minima) are highly sensitive to changing climate, and 558 these timing changes have extensive negative impacts on cold IBI.

For climate change adaptation measures and targeting of critically vulnerable streams, 560 analysis at the local scale is critical to stream protection. A probability map of declining stream 561 health indicators is presented for the Pere Marquette-White watershed in Figure 8, which 562 demonstrates the reach scale variability in probability of decline. The same figure for the 563 complete study area (IBI) is presented in Figure A5 of the Supplementary Materials. For 564 example, Figure 8a (EPT) demonstrates the overall agreement between the CDFs in Figure 7 and 565 the individual reaches, in that risk of declining EPT is relatively low across the watershed. 566 However, several individual reaches are highly likely to experience declines in stream health. 
A map that describes the average magnitude of stream health decline (Figure 9) can be 568 multiplied by the probability map (Figure 8). This combination identifies locations that have a 569 large risk of declining stream health coupled with a large magnitude of decline. In locations

570 where these conditions are met, individual streams should be classified as critically threatened by

571 climate change. The 'unacceptable' levels of risk and magnitude of stream health degradation

572 could be defined by watershed stakeholders and natural resource managers to determine

573 locations to target adaptation and stream protection measures. This process was completed in

574 Figure 10 using the Jenks natural breaks method to define low, medium, and high vulnerability

575 streams for the Pere Marquette-White watershed. There are few locations that are highly

576 vulnerable in the watershed, as most of the streams were experienced to project low or no

577 vulnerability. The magnitude of declining IBI and risk of declining IBI are presented in Figure 578 A6 and Figure A7 of the Supplementary Materials, respectively.

Figure 8.

580

581

Figure 9.

Figure 10.

\section{CONCLUSIONS}

The primary objective of this study was to determine the impacts of projected climate 586 changes on stream health. Initially, watershed models were developed for seven watersheds in

587 Michigan (Woznicki, 2015) encompassing four stream thermal classes (cold, cold-transitional, 588 cool, and warm). Bayesian variable selection (Woznicki et al., 2015) was used to select 
589 influential flow regime and water quality variables for development of ANFIS stream health 590 models for EPT, FIBI, HBI, and IBI. The watershed and stream health models were then driven 591 by climate scenarios from the multi-model CMIP5 ensemble to develop projections of stream 592 health in 2020-2040 as compared to the baseline 1980-2000. A stream temperature regression 593 model was also developed to identify shifts in stream thermal classes as defined by July mean 594 stream temperature.

Several flow regime variables exhibited sensitivity to changing precipitation and temperature. Flow variability, timing of flooding and low flow events, and duration of low and 597 high flow events were affected by climate change and resulted in changes to stream health 598 indicators across thermal regimes. Reduced flow variability was critical to maintaining the health 599 of stable groundwater-fed cold streams. Meanwhile, slight increases in flow variability proved to 600 be important to the health of more flashy runoff-driven warm streams.

Changes in thermal class due to stream temperature increases were also examined,

602 because these shifts may affect the community composition of a stream. These shifts in thermal 603 class were determined to occur mostly in the transitional thermal regimes (cold-transitional to 604 cool and cool to warm). The greatest concern was extreme shifts from streams classified as cold 605 to cool or warm because of the temperature sensitivity of many coldwater species, but the stream 606 temperature increases were never projected to be large enough for this to occur. Changes in stream health were depicted using CDFs to identify indicators and thermal 608 classes that were at risk of declining health under future climate change. In addition, the CDFs 609 characterized the overall sensitivity of a stream health indicator to climate change. The average 610 response of stream health indicators was generally insensitive to changing climate. However, 
611 when analyzing risk and magnitude of declining stream health on a localized reach-level basis,

612 the impacts of climate change were more pronounced. This demonstrates the importance of

613 vulnerability assessment in development of potential adaptation measures.

614 There are limitations related to use of the change factor method in development of the

615 climate change ensemble. Future studies will benefit from including multiple sources of climate

616 data and multiple downscaling and bias correction methods, including those that do not adhere to

617 the stationarity assumption. However, the assessment framework presented in this study is robust

618 in that any climate data and downscaling and bias correction methods could be easily

619 incorporated here.

The results of this study demonstrate the potential impacts of climate change on stream

621 health and the applicability of the model development process to characterize these changes.

622 Projected future risks of declining stream health and magnitude of decline varied considerably at

623 the reach scale, and less so when examined at larger scales. Therefore, in guiding natural

624 resource managers and watershed stakeholders in protecting stream ecosystems and developing

625 adaptation plans to combat projected climate change, decision-making at the reach level will

626 likely lead to greater success. The climate change impact assessment process presented here is

627 transferrable to other watersheds and can be extended to explore the potential benefits of

628 adopting climate change adaptation measures at both large and localized scales.

\section{ACKNOWLEDGEMENTS}

631 Modelling, which is responsible for CMIP, and we thank the climate modeling groups (listed in 632 Table 3 of this paper) for producing and making available their model output. For CMIP the U.S. 
Department of Energy's Program for Climate Model Diagnosis and Intercomparison provides coordinating support and led development of software infrastructure in partnership with the Global Organization for Earth System Science Portals. The climate projections were developed with funding from the National Science Foundation under Grant BCS-0909378. Any opinions, findings, and conclusions or recommendations expressed in this material are those of the authors and do not necessarily reflect the views of the National Science Foundation. We thank Dr. Travis Brenden, Associate Professor/Associate Director of the Quantitative Fisheries Center at Michigan State University for SAS code for the stream temperature model. This work is supported by the USDA National Institute of Food and Agriculture, Hatch project MICL02212.

\section{REFERENCES}

Abbaspour, K.C., Faramarzi, M., Ghasemi, S.S., Yang, H., 2009. Assessing the impact of climate change on water resources in Iran. Water Resources Research 45, W10434.

Adriaenssens, V., Baets, B.D., Goethals, P.L.M., Pauw, N.D., 2004. Fuzzy rule-based models for decision support in ecosystem management. Science of The Total Environment 319, 112.

Arnold, J.G., Moriasi, D.N., Gassman, P.W., Abbaspour, K.C., White, M.J., Srinivasan, R., Santhi, C., Harmel, R.D., Van Griensven, A., Van Liew, M.W., others, 2012. SWAT: Model use, calibration, and validation. Transactions of the ASABE 55, 1491-1508.

Arnold, J.G., Srinivasan, R., Muttiah, R.S., Williams, J.R., 1998. Large area hydrologic modeling and assessment. Part I: model development. Water Resources Bulletin 34, 7389. 
654 Bae, D.-H., Jung, I.-W., Lettenmaier, D.P., 2011. Hydrologic uncertainties in climate change 655

656

657

658

Balke, K.L., U’Ren, S., Kohler, E., 2011. Pere Marquette River Watershed Management Plan. from IPCC AR4 GCM simulations of the Chungju Basin, Korea. Journal of Hydrology 401, 90-105.

659

660

661

662

663

664

665

666

667

668

669

670

671

672 Conservation Resource Alliance.

Barbour, M.T., Gerritsen, J., Snyder, B.D., Stribling, J.B., 1999. Rapid bioassessment protocols for use in streams and wadeable rivers: periphyton, benthic macroinvertebrates, and fish (No. EPA 841-B-99-002). USEPA, Washington, DC.

Bastola, S., Murphy, C., Sweeney, J., 2011. The sensitivity of fluvial flood risk in Irish catchments to the range of IPCC AR4 climate change scenarios. Science of The Total Environment 409, 5403-5415.

Boé, J., Terray, L., Martin, E., Habets, F., 2009. Projected changes in components of the hydrological cycle in French river basins during the 21 st century. Water Resources Research 45, W08426.

Boyer, C., Chaumont, D., Chartier, I., Roy, A.G., 2010. Impact of climate change on the hydrology of St. Lawrence tributaries. Journal of Hydrology 384, 65-83.

Bunn, S.E., Arthington, A.H., 2002. Basic principles and ecological consequences of altered flow regimes for aquatic biodiversity. Environmental Management 30, 492-507.

72 Caissie, D., 2006. The thermal regime of rivers: a review. Freshwater Biology 51, 1389-1406. 
673 Chen, H., Xu, C.-Y., Guo, S., 2012. Comparison and evaluation of multiple GCMs, statistical

674

675

676

677

678

679

680

681

682

683

684

685

686

687

688

689

690 downscaling and hydrological models in the study of climate change impacts on runoff. Journal of Hydrology 434-435, 36-45.

Chen, Q., Mynett, A.E., 2003. Integration of data mining techniques and heuristic knowledge in fuzzy logic modelling of eutrophication in Taihu Lake. Ecological Modelling 162, 55-67.

Chessman, B.C., 2009. Climatic changes and 13-year trends in stream macroinvertebrate assemblages in New South Wales, Australia. Global Change Biology 15, 2791-2802.

Chiew, F.H.S., Teng, J., Vaze, J., Post, D.A., Perraud, J.M., Kirono, D.G.C., Viney, N.R., 2009. Estimating climate change impact on runoff across southeast Australia: method, results, and implications of the modeling method. Water Resources Research 45, W10414.

Clapcott, J.E., Collier, K.J., Death, R.G., Goodwin, E.O., Harding, J.S., Kelly, D., Leathwick, J.R., Young, R.G., 2012. Quantifying relationships between land-use gradients and structural and functional indicators of stream ecological integrity: stream integrity along land-use gradients. Freshwater Biology 57, 74-90.

DeWeber, J.T., Wagner, T., 2014. A regional neural network ensemble for predicting mean daily river water temperature. Journal of Hydrology 517, 187-200.

Dodge, K.E., 1998. River Raisin Assessment. Michigan Department of Natural Resources, Fisheries Division Special Report 23. 
Domisch, S., JäHnig, S.C., Haase, P., 2011. Climate-change winners and losers: stream macroinvertebrates of a submontane region in Central Europe: climate change effects on stream macroinvertebrates. Freshwater Biology 56, 2009-2020.

Durance, I., Ormerod, S.J., 2007. Climate change effects on upland stream macroinvertebrates over a 25-year period. Global Change Biology 13, 942-957.

Einheuser, M.D., Nejadhashemi, A.P., Sowa, S.P., Wang, L., Hamaamin, Y.A., Woznicki, S.A., 2012. Modeling the effects of conservation practices on stream health. Science of The Total Environment 435-436, 380-391.

Einheuser, M.D., Nejadhashemi, A.P., Woznicki, S.A., 2013. Simulating stream health sensitivity to landscape changes due to bioenergy crops expansion. Biomass and Bioenergy 58, 198-209.

Elsner, M.M., Cuo, L., Voisin, N., Deems, J.S., Hamlet, A.F., Vano, J.A., Mickelson, K.E.B., Lee, S.-Y., Lettenmaier, D.P., 2010. Implications of 21 st century climate change for the hydrology of Washington State. Climatic Change 102, 225-260.

Fiseha, B.M., Setegn, S.G., Melesse, A.M., Volpi, E., Fiori, A., 2014. Impact of climate change on the hydrology of Upper Tiber River basin using bias corrected regional climate model. Water Resources Management 28, 1327-1343.

Flinders, C.A., Horwitz, R.J., Belton, T., 2008. Relationship of fish and macroinvertebrate communities in the mid-Atlantic uplands: Implications for integrated assessments. Ecological Indicators 8, 588-598. 
711 Fowler, H.J., Blenkinsop, S., Tebaldi, C., 2007. Linking climate change modelling to impacts studies: recent advances in downscaling techniques for hydrological modelling. International Journal of Climatology 27, 1547-1578.

Gädeke, A., Hölzel, H., Koch, H., Pohle, I., Grünewald, U., 2014. Analysis of uncertainties in the hydrological response of a model-based climate change impact assessment in a subcatchment of the Spree River, Germany. Hydrological Processes 28, 3978-3998.

Green, P.J., 1995. Reversible jump Markov Chain Monte Carlo computation and Bayesian model determination. Biometrika 82, 711-732.

Herman, M.R., Nejadhashemi, A.P., 2015. A review of macroinvertebrate- and fish-based stream health indices. Ecohydrology \& Hydrobiology 15(2): 53-67.

Hilsenhoff, W.L., 1988. Rapid field assessment of organic pollution with a family-level biotic index. Journal of the North American Benthological Society 7, 65-68.

IPCC, 2014. Climate Change 2014: Impacts, Adaptation, and Vulnerability. Part A: Global and Sectoral Aspects. Contribution of Working Group II to the Fifth Assessment Report of the Intergovernmental Panel on Climate Change. Cambridge University Press, Cambridge, United Kingdom and New York, NY, USA.

IPCC, 2013. Climate Change 2013: The Physical Science Basis. Contribution of Working Group I to the Fifth Assessment Report of the Intergovernmental Panel on Climate Change. Cambridge University Press, Cambridge, United Kingdom and New York, NY, USA. 
Isaak, D.J., Wollrab, S., Horan, D., Chandler, G., 2012. Climate change effects on stream and river temperatures across the northwest U.S. from 1980-2009 and implications for salmonid fishes. Climatic Change 113, 499-524.

Jang, J.-S.R., 1993. ANFIS: adaptive-network-based fuzzy inference system. IEEE Transactions on Systems, Man and Cybernetics 23, 665-685.

Kalish, T.G., Tonello, M.A., 2014. Boardman River Assessment. Michigan Department of Natural Resources, Fisheries Division Special Report Draft.

Karr, J.R., 1987. Biological monitoring and environmental assessment: a conceptual framework. Environmental Management 11, 249-256.

Lawrence, J.E., Lunde, K.B., Mazor, R.D., Bêche, L.A., McElravy, E.P., Resh, V.H., 2010. Long-term macroinvertebrate responses to climate change: implications for biological assessment in mediterranean-climate streams. Journal of the North American Benthological Society 29, 1424-1440.

Leibowitz, S.G., Comeleo, R.L., Wigington Jr., P.J., Weaver, C.P., Morefield, P.E., Sproles, E.A., Ebersole, J.L., 2014. Hydrologic landscape classification evaluates streamflow vulnerability to climate change in Oregon, USA. Hydrology and Earth System Sciences $18,3367-3392$.

Leonardi, J.M., Gruhn, W.J., 2001. Flint River Assessment. Michigan Department of Natural Resources, Fisheries Division Special Report 27. 
749

750

751

752

753

754

755

756

757

758

759

760

761

762

763

764

765

766

767

Leunda, P.M., Oscoz, J., Miranda, R., Ariño, A.H., 2009. Longitudinal and seasonal variation of the benthic macroinvertebrate community and biotic indices in an undisturbed Pyrenean river. Ecological Indicators 9, 52-63.

Lyons, J., 1992. Using the index of biotic integrity (IBI) to measure environmental quality in warmwater streams of Wisconsin. (No. NC-149). United States Department of Agriculture, Forest Service, North Central Forest Experiment Station, St. Paul, MN.

Lyons, J., Wang, L., Simonson, T.D., 1996. Development and validation of an index of biotic integrity for coldwater streams in Wisconsin. North American Journal of Fisheries Management 16, 241-256.

Lyons, J., Zorn, T., Stewart, J., Seelbach, P., Wehrly, K., Wang, L., 2009. Defining and characterizing coolwater streams and their fish assemblages in Michigan and Wisconsin, USA. North American Journal of Fisheries Management 29, 1130-1151.

Lytle, D.A., Poff, N.L., 2004. Adaptation to natural flow regimes. Trends in Ecology \& Evolution 19, 94-100.

Marchini, A., Facchinetti, T., Mistri, M., 2009. F-IND: A framework to design fuzzy indices of environmental conditions. Ecological Indicators 9, 485-496.

Mazor, R.D., Purcell, A.H., Resh, V.H., 2009. Long-term variability in bioassessments: a twenty-year study from two northern California streams. Environmental Management 43, 1269-1286. 
McDaniels, T., Wilmot, S., Healey, M., Hinch, S., 2010. Vulnerability of Fraser River sockeye salmon to climate change: a life cycle perspective using expert judgments. Journal of Environmental Management 91, 2771-2780.

MDEQ, 1997. GLEAS Procedure \#51 Surve Protocols for Wadable Rivers (No. Fisheries Special Report 25), Manual of Fisheries Survey Methods II: with periodic updates. Michigan Department of Environmental Quality, Surface Water Quality Division, Ann Arbor, MI.

Moss, R.H., Edmonds, J.A., Hibbard, K.A., Manning, M.R., Rose, S.K., van Vuuren, D.P., Carter, T.R., Emori, S., Kainuma, M., Kram, T., Meehl, G.A., Mitchell, J.F.B., Nakicenovic, N., Riahi, K., Smith, S.J., Stouffer, R.J., Thomson, A.M., Weyant, J.P., Wilbanks, T.J., 2010. The next generation of scenarios for climate change research and assessment. Nature 463, 747-756.

Nakicenovic, N., Swart, R., 2000. Special Report on Emissions Scenarios: A Special Report of Working Group III of the Intergovernmental Panel on Climate Change. Cambridge University Press, Cambridge, United Kingdom and New York, NY, USA.

Nash, J.E., Sutcliffe, J.V., 1970. River flow forecasting through conceptual models part I — A discussion of principles. Journal of Hydrology 10, 282-290.

NASS, 2012. USDA National Agricultural Statistics Service Cropland Data Layer. Published crop-specific data layer.

NCDC, 2015. NCDC Climate Data Online. 
788 NED, 2014. USGS National Elevation Dataset.

789 Neitsch, S.L., Arnold, J.G., Kiniry, J.R., Williams, J.R., 2005. Soil and Water Assessment Tool 790 theoretical documentation, version 2005. USDA Agricultural Research Service, Temple, 791 TX.

792 NHDPlus, 2015. National Hydrography Datset Plus v2. Horizon Systems [WWW Document]. 793 URL http://www.horizon-systems.com/nhdplus/ (accessed 4.15.15).

794 NRCS, 2015. Digital General Soil Map of the United States (STATSGO2). Soil Survey Staff, 795 Natural Resources Conservation Service, United States Department of Agriculture. Web 796 Soil Survey [WWW Document]. URL http://websoilsurvey.nrcs.usda.gov/ (accessed 797 4.15.15).

798 NRCS, 2014. Soil Survey Geographic Database (SSURGO). Soil Survey Staff, Natural 799 Resources Conservation Service, United States Department of Agriculture. Web Soil $800 \quad$ Survey.

801 Olden, J.D., Naiman, R.J., 2010. Incorporating thermal regimes into environmental flows 802 assessments: modifying dam operations to restore freshwater ecosystem integrity. 803 Freshwater Biology 55, 86-107.

804 O’Neal, R.P., 1997. Muskegon River Watershed Assessment. Michigan Department of Natural 805 Resources, Fisheries Division Special Report 19. 
Piani, C., Weedon, G.P., Best, M., Gomes, S.M., Viterbo, P., Hagemann, S., Haerter, J.O., 2010. Statistical bias correction of global simulated daily precipitation and temperature for the application of hydrological models. Journal of Hydrology 395, 199-215.

Poff, N.L., Allan, J.D., Bain, M.B., Karr, J.R., Prestegaard, K.L., Richter, B.D., Sparks, R.E., Stromberg, J.C., 1997. The natural flow regime. BioScience 47, 769-784.

Pont, D., Hughes, R.M., Whittier, T.R., Schmutz, S., 2009. A predictive index of biotic integrity model for aquatic-vertebrate assemblages of western U.S. Streams. Transactions of the American Fisheries Society 138, 292-305.

Poole, G.C., Berman, C.H., 2001. An ecological perspective on in-stream temperature: natural heat dynamics and mechanisms of human-causedthermal degradation. Environmental Management 27, 787-802.

Praskievicz, S., Bartlein, P., 2014. Hydrologic modeling using elevationally adjusted NARR and NARCCAP regional climate-model simulations: Tucannon River, Washington. Journal of Hydrology 517, 803-814.

PRISM Climate Group, 2015. PRISM Climate Data [WWW Document]. URL http://www.prism.oregonstate.edu/

Prudhomme, C., Giuntoli, I., Robinson, E.L., Clark, D.B., Arnell, N.W., Dankers, R., Fekete, B.M., Franssen, W., Gerten, D., Gosling, S.N., Hagemann, S., Hannah, D.M., Kim, H., Masaki, Y., Satoh, Y., Stacke, T., Wada, Y., Wisser, D., 2014. Hydrological droughts in the 21 st century, hotspots and uncertainties from a global multimodel ensemble experiment. Proceedings of the National Academy of Sciences 111, 3262-3267. 
827 Prudhomme, C., Wilby, R.L., Crooks, S., Kay, A.L., Reynard, N.S., 2010. Scenario-neutral approach to climate change impact studies: application to flood risk. Journal of Hydrology 390, 198-209.

830 831

Rahel, F.J., Keleher, C.J., Anderson, J.L., 1996. Potential habitat loss and population fragmentation for cold water fish in the North Platte River drainage of the Rocky Mountains: response to climate warming. Limnology and Oceanography 41, 1116-1123.

SAS Institute, 2015. SAS. SAS Institute, Cary, NC.

Schabenberger, O., 2005. Introducing the GLIMMIX procedure for generalized linear mixed models, in: Proceedings of the 30th Annual SAS Users Group International Conference. Presented at the SUGI 30, Philadelphia, PA, p. 20.

Steen, P.J., Zorn, T.G., Seelbach, P.W., Schaeffer, J.S., 2008. Classification tree models for predicting distributions of Michigan stream fish from landscape variables. Transactions of the American Fisheries Society 137, 976-996.

Taylor, K.E., Stouffer, R.J., Meehl, G.A., 2011. An overview of CMIP5 and the experiment design. Bulletin of the American Meteorological Society 93, 485-498.

Teutschbein, C., Seibert, J., 2012. Bias correction of regional climate model simulations for hydrological climate-change impact studies: review and evaluation of different methods. Journal of Hydrology 456-457, 12-29. doi:10.1016/j.jhydrol.2012.05.052 
Wang, L., Robertson, D.M., Garrison, P.J., 2007. Linkages between nutrients and assemblages of macroinvertebrates and fish in wadeable streams: Implication to nutrient criteria development. Environmental Management 39, 194-212.

Wang, L., Brenden, T., Seelbach, P., Cooper, A., Allan, D., Jr, R.C., Wiley, M., 2008. Landscape based identification of human disturbance gradients and reference conditions for Michigan streams. Environmental Monitoring and Assessment 141, 1-17.

Wang, L., Brenden, T., Cao, Y., Seelbach, P., 2012. Delineation and validation of river network spatial scales for water resources and fisheries management. Environmental Management $50,875-887$.

Weber, E.U., 2006. Experience-based and description-based perceptions of long-term risk: why global warming does not scare us (yet). Climatic Change 77, 103-120.

Wehrly, K.E., Brenden, T.O., Wang, L., 2009. A comparison of statistical approaches for predicting stream temperatures across heterogeneous Landscapes. Journal of the American Water Resources Association 45, 986-997.

Wehrly, K.E., Wiley, M.J., Seelbach, P.W., 2003. Classifying regional variation in thermal regime based on stream fish community patterns. Transactions of the American Fisheries Society $132,18-38$.

Winkler, J.A., Guentchev, G.S., Liszewska, M., Perdinan, Tan, P.-N., 2011. Climate scenario development and applications for local/regional climate change impact assessments: an overview for the non-climate scientist: part II: considerations when using climate change scenarios. Geography Compass 5, 301-328. 
866 Woodward, G., Perkins, D.M., Brown, L.E., 2010. Climate change and freshwater ecosystems: impacts across multiple levels of organization. Philosophical Transactions of the Royal Society B: Biological Sciences 365, 2093-2106.

869 Woznicki, S.A., Nejadhashemi, A.P., Ross, D.M., Zhang, Z., Wang, L., Esfahanian, A.-H., 2015. Ecohydrological model parameter selection for stream health evaluation. Science of The Total Environment 511, 341-353.

872 Woznicki, S.A., 2015. Development of comprehensive framework to assess the impacts of climate change on stream health. PhD Dissertation, East Lansing, Michigan, USA.

874 Zorn, T.G., Seelbach, P.W., Rutherford, E.S., Wills, T.C., Cheng, S.T., Wiley, M.J., 2008. A 875 regional-scale habitat suitability model to assess the effects of flow reduction on fish assemblages in Michigan streams (No. Fisheries Research Report 2089). Michigan Department of Natural Resources, Ann Arbor, MI.

878 Zorn, T.G., Sendek, S.P., 2001. Au Sable River Assessment (No. Special Report 26). Michigan Department of Natural Resources, Fisheries Division, Ann Arbor, MI. 


\section{Figure Captions:}

Figure 1. Stream thermal classes for (a) Au Sable, (b) Boardman-Charlevoix, (c) Cedar-Ford, (d) Flint, (e) Muskegon, (f) Pere-Marquette-White, and (g) Raisin; (h) watershed locations in Michigan

Figure 2. Modeling process

Figure 3. Monthly change factors across all climate models and RCPs for (a) precipitation, (b) maximum temperature, and (c) minimum temperature

Figure 4. Stream health for cold streams as a function of percent change in flow regime variable under future climate scenarios. Spearman's $\rho$ values are presented in the top right of each figure, and red dots indicate baseline stream health. Variable definitions are provided in the supplementary materials

Figure 5. Percent change in stream thermal classes

Figure 6. Probability of shifted thermal class due to climate change for the Pere Marquette-White watershed

Figure 7. Average stream health CDFs of each thermal class and stream health indicator, where the black line is comprised of the climate scenarios (2020-2040) and the red dot is the baseline stream health (1980-2000)

Figure 8. Probability of declining (a) EPT, (b) FIBI, (c) HBI, and d (IBI) under projected climate change for the Pere Marquette-White watershed

Figure 9. Average magnitude of change in (a) EPT, (b) FIBI, (c) HBI, and d (IBI) under projected climate change. Symbology is reversed for HBI because lower values are better 
Figure 10. Map combining risk of declining stream health with average magnitude of declining stream health across all climate scenarios for (a) EPT, (b) FIBI, (c) HBI, and d (IBI). This represents the vulnerability of degraded stream health in 2020-2040 


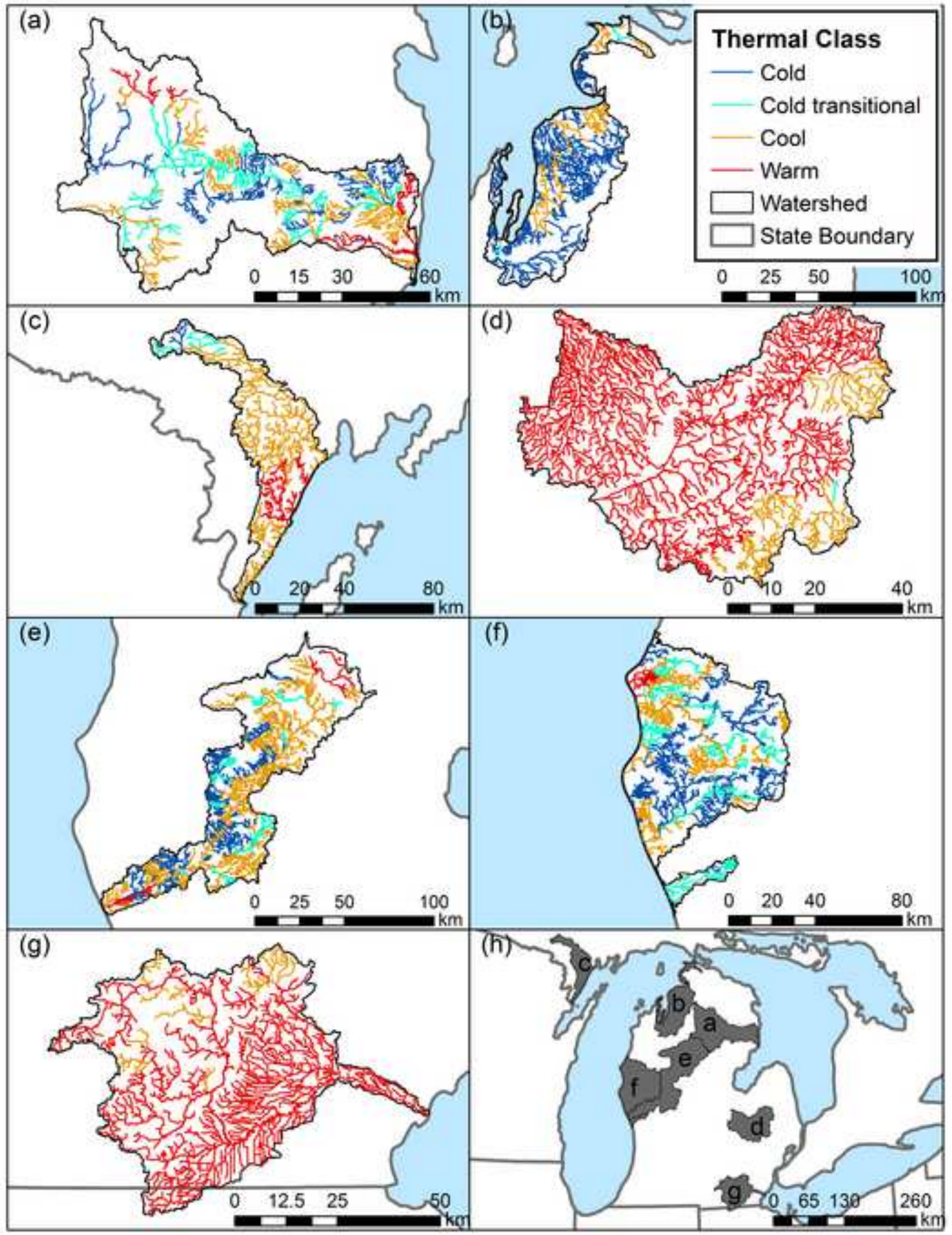




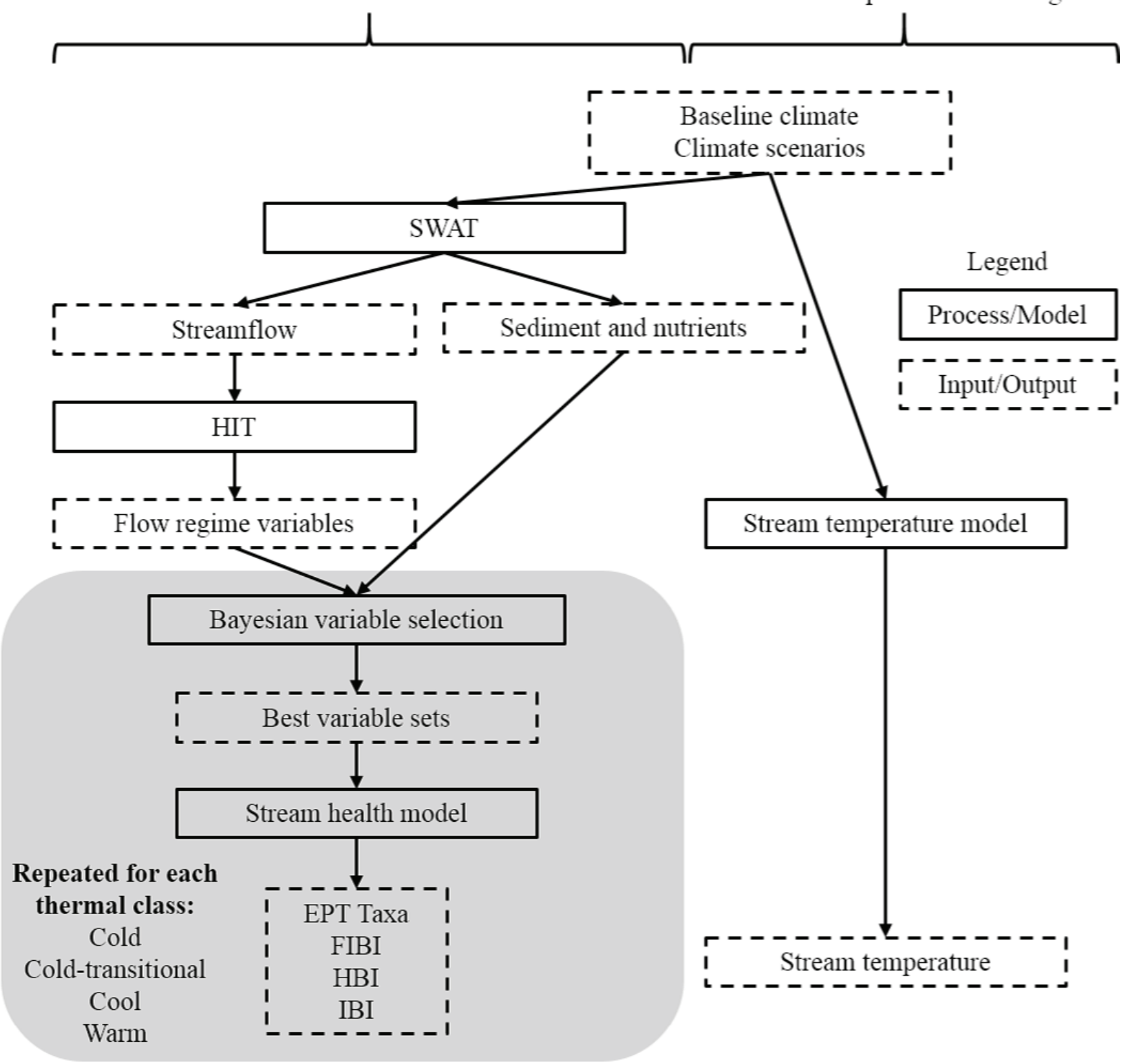



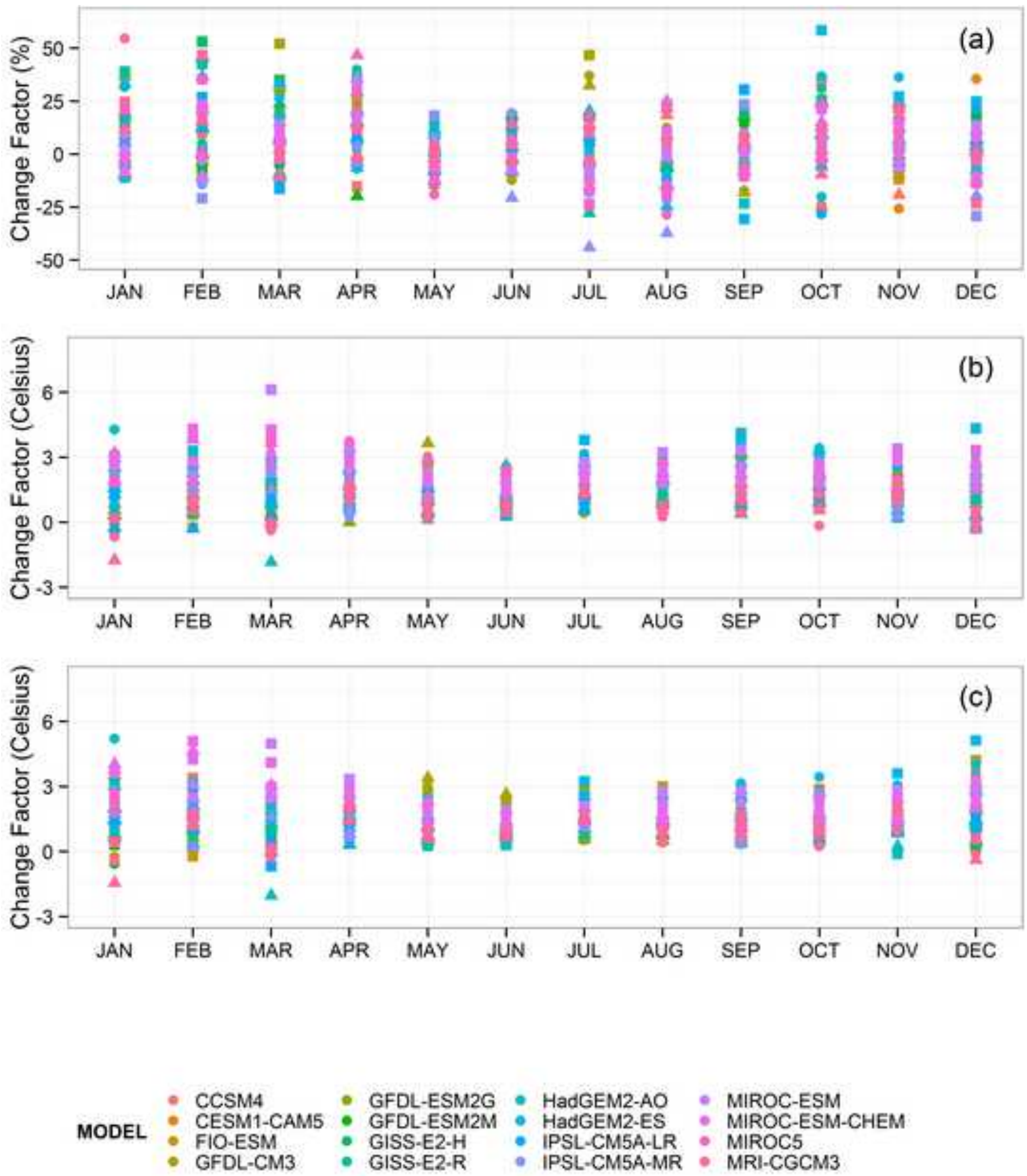

EXPERIMENT • RCP4.5 « RCP6.0 - RCP8.5 

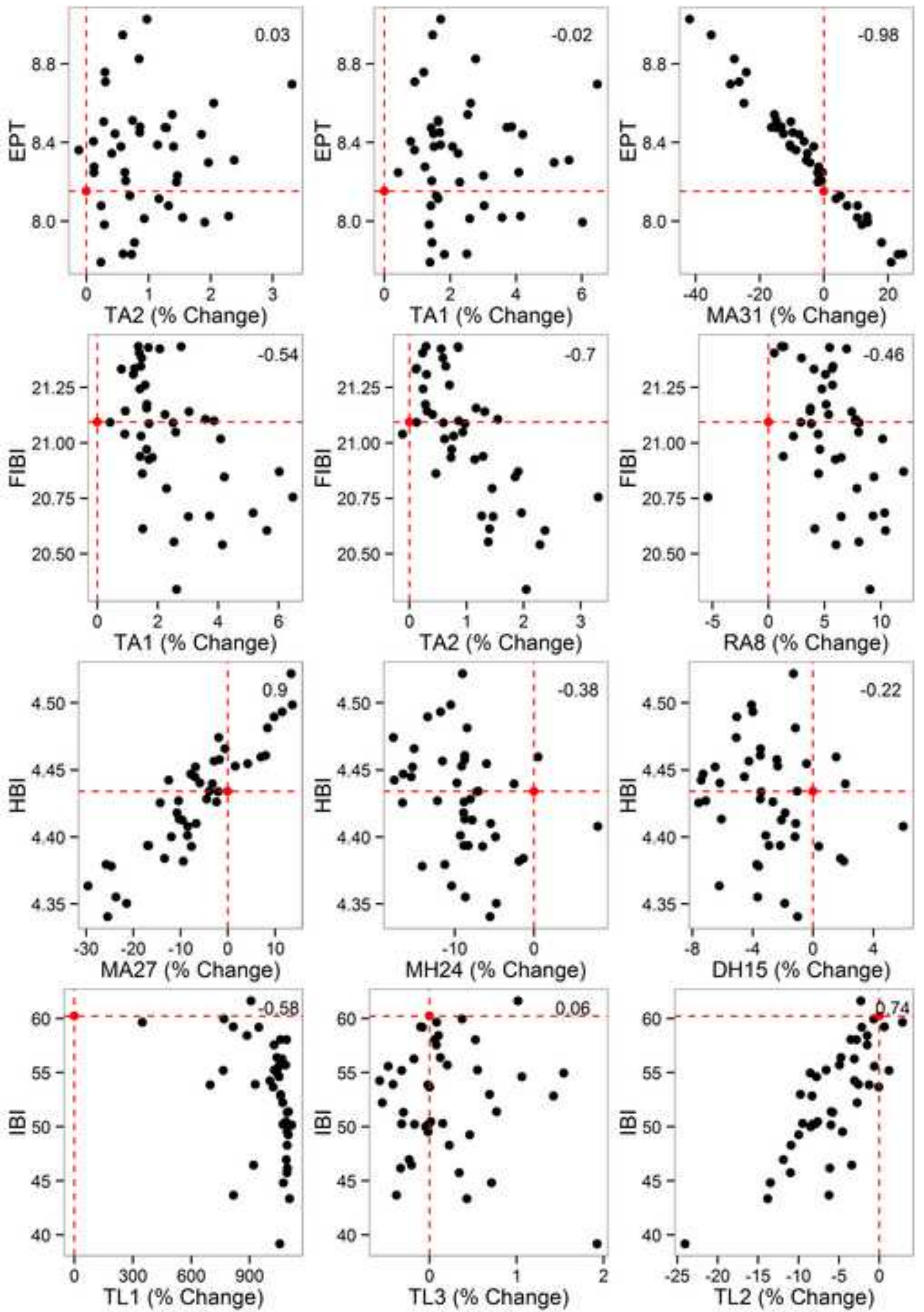


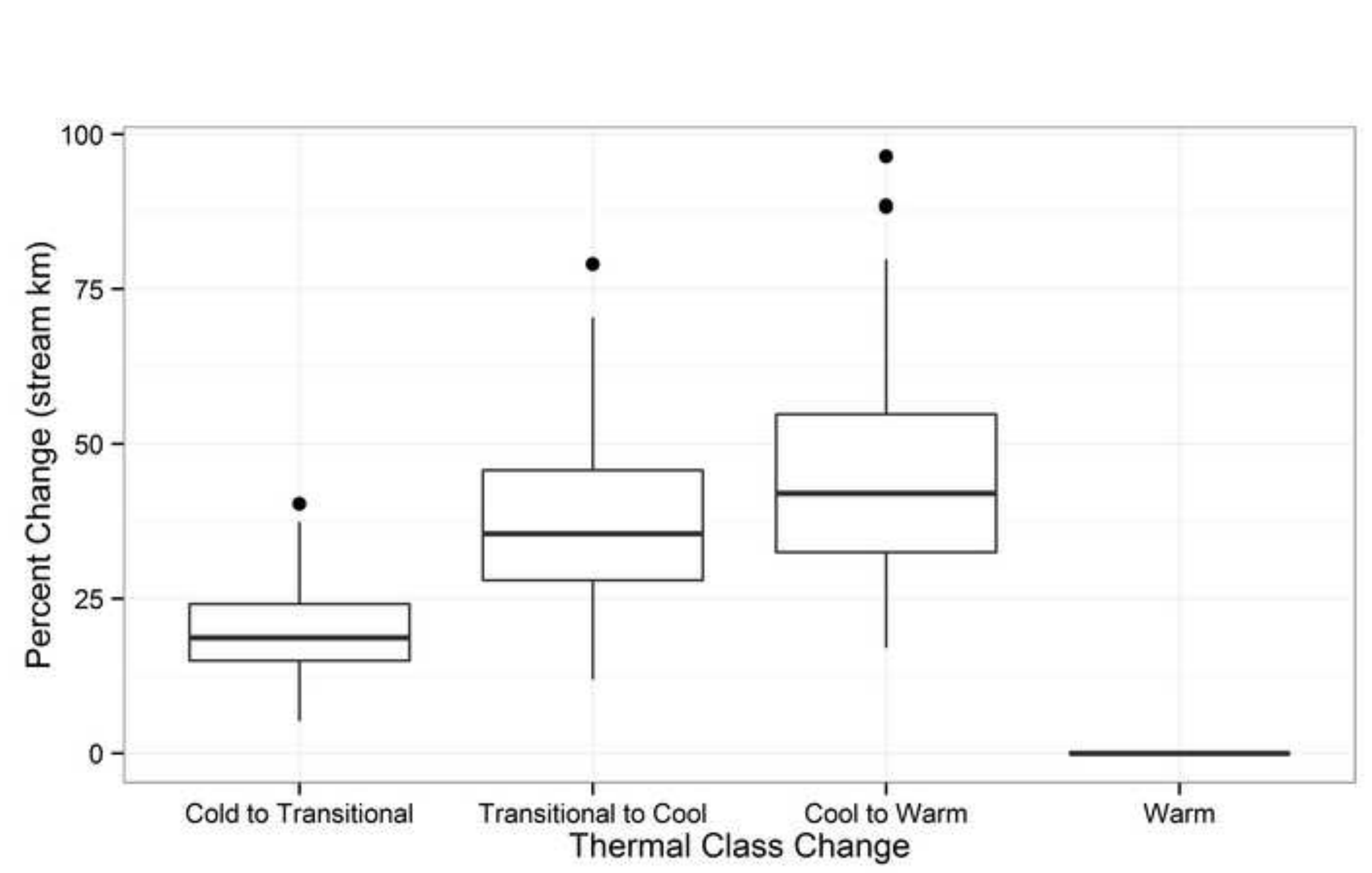




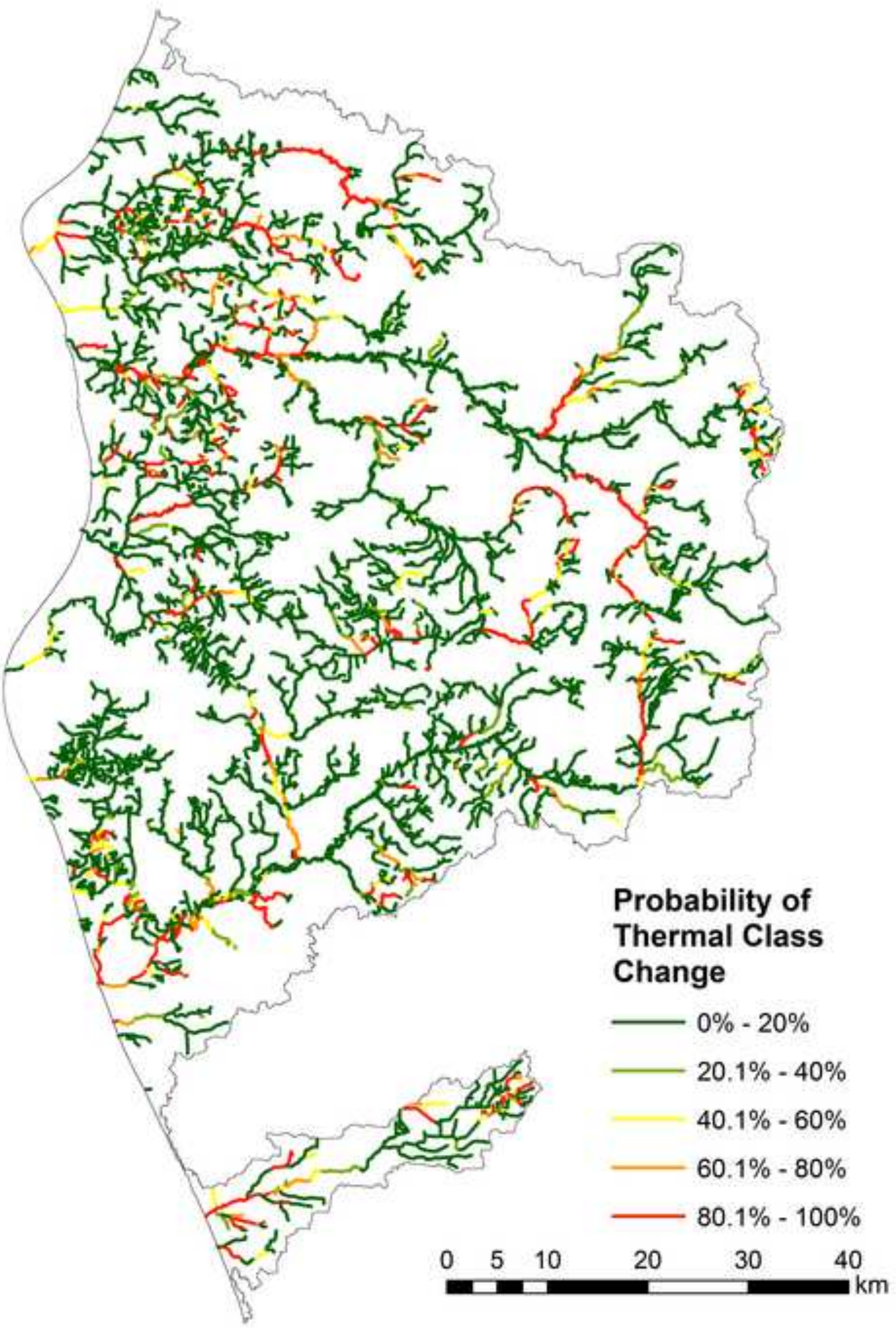



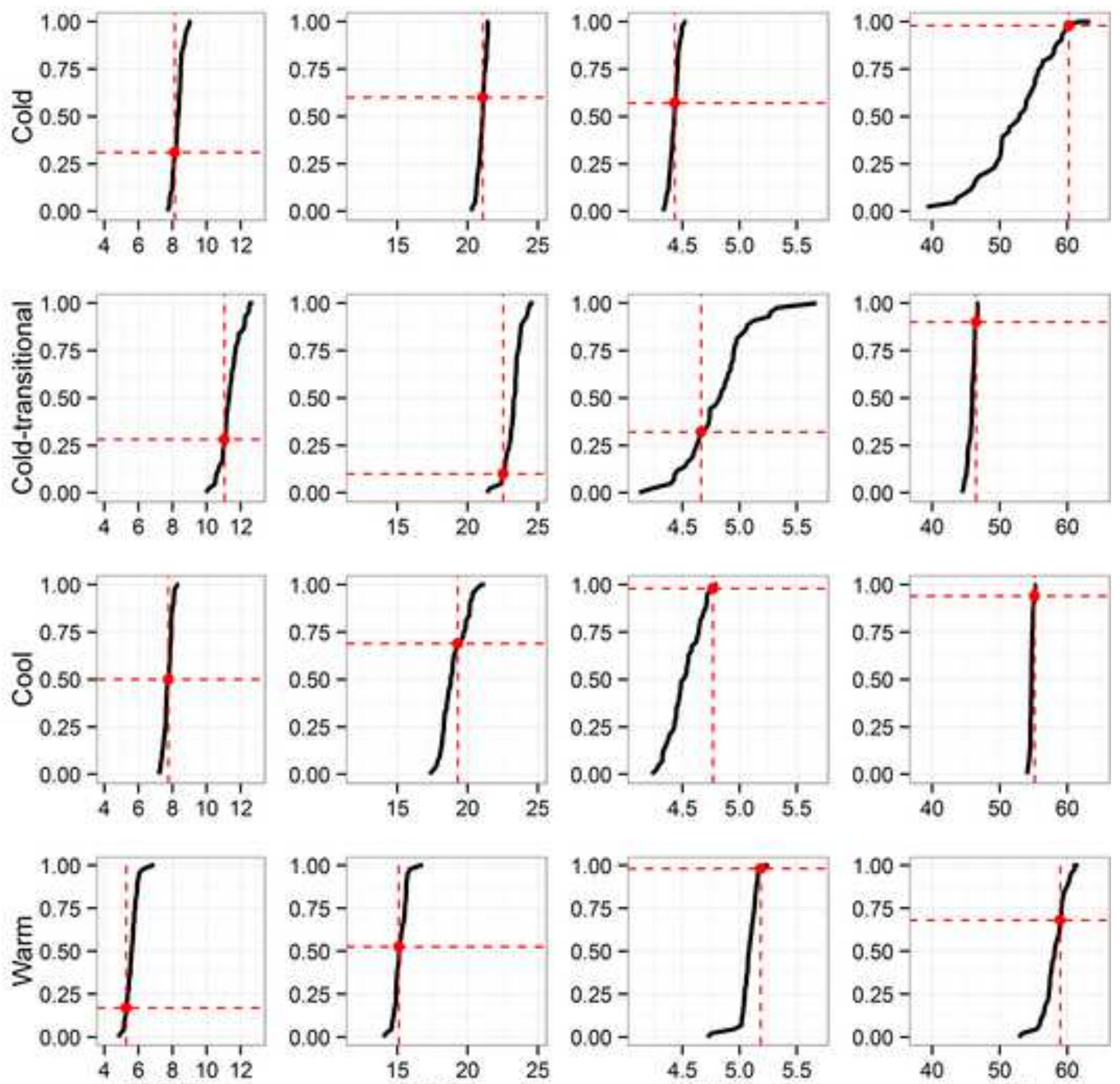

EPT Taxa

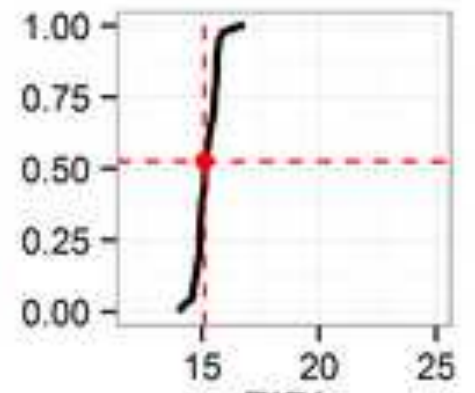

FIBI
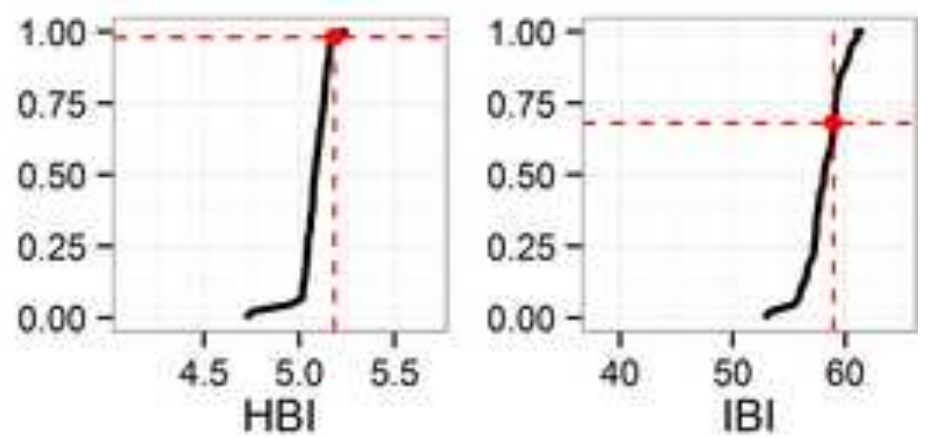
Figure 8

(a)

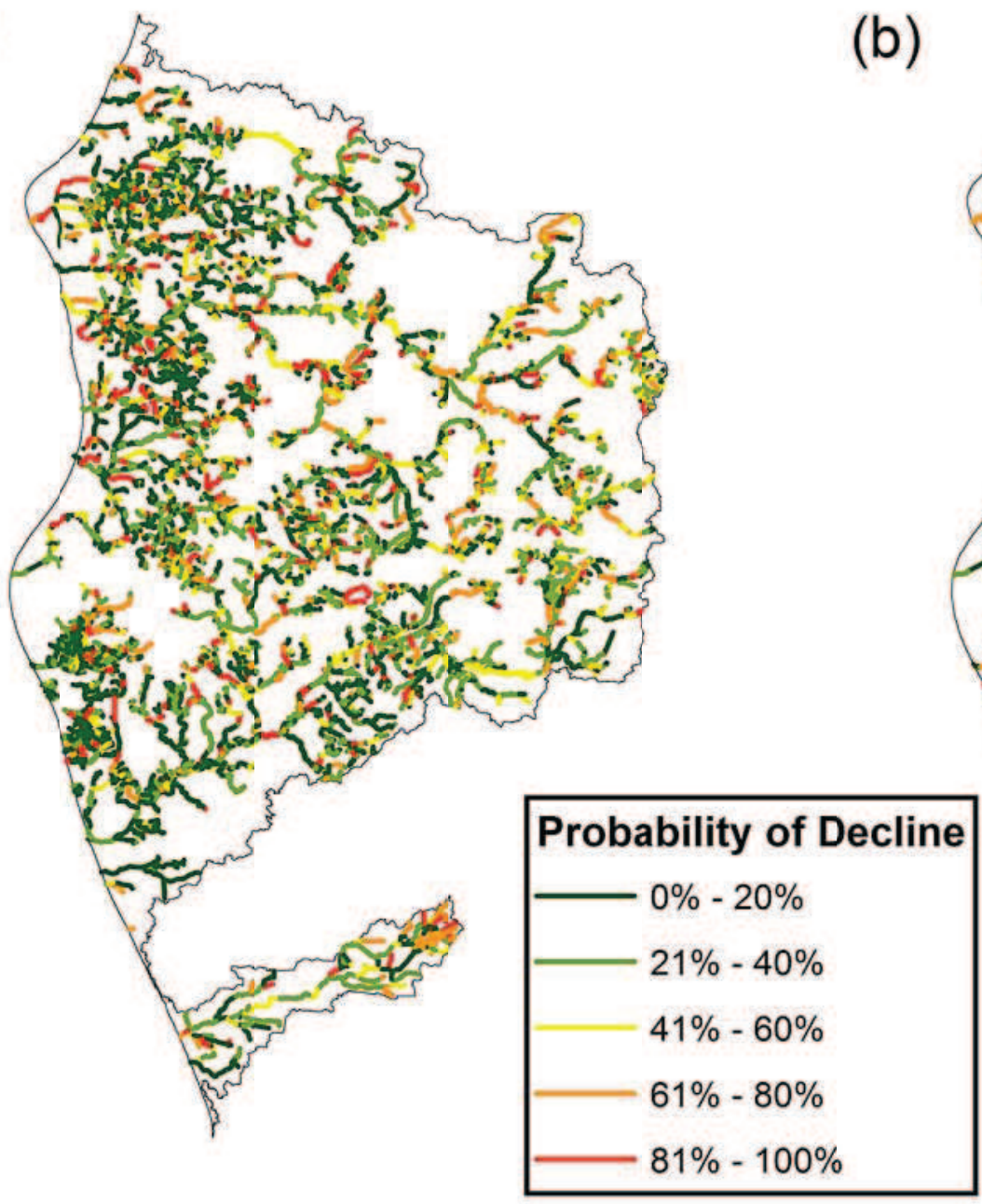

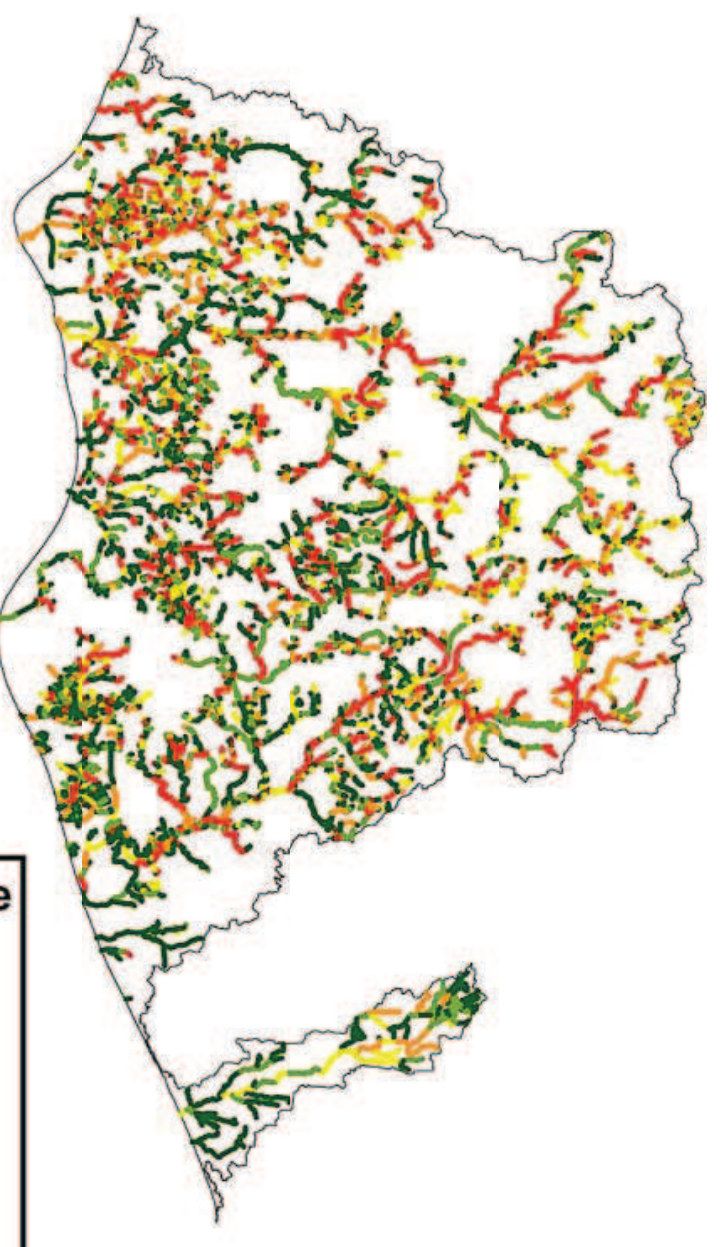

(c)

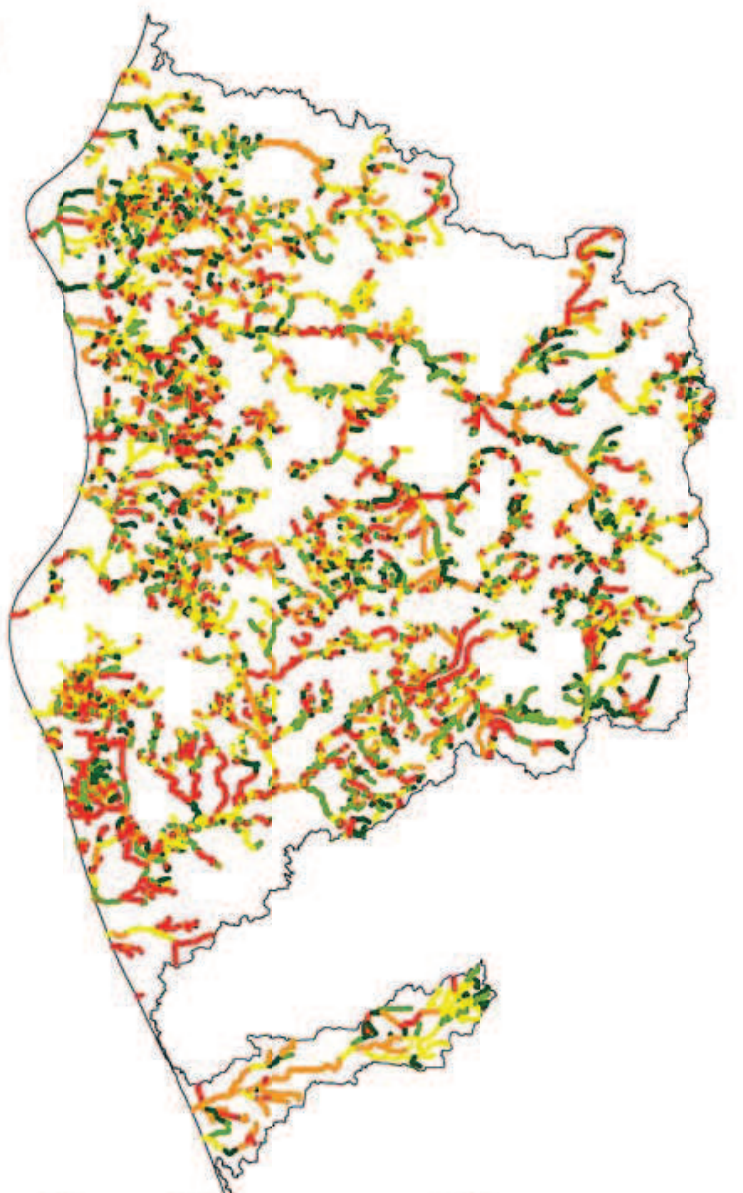

(d)

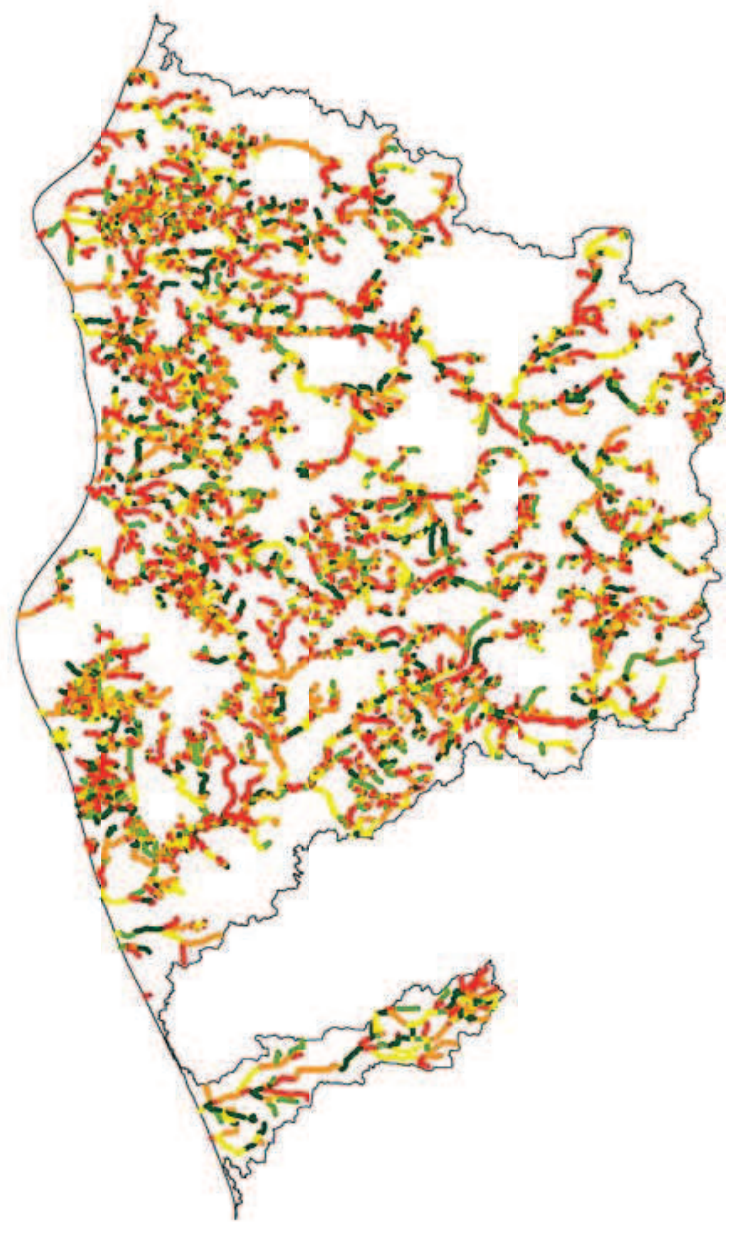


(a)

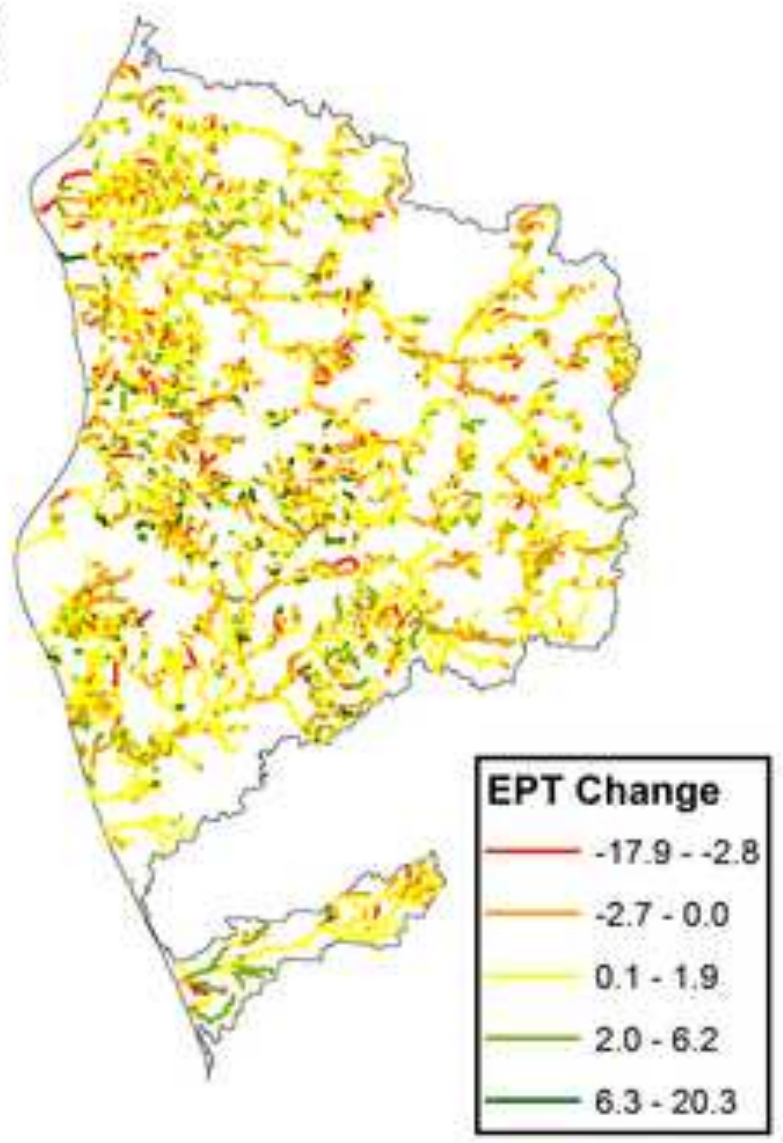

(c)

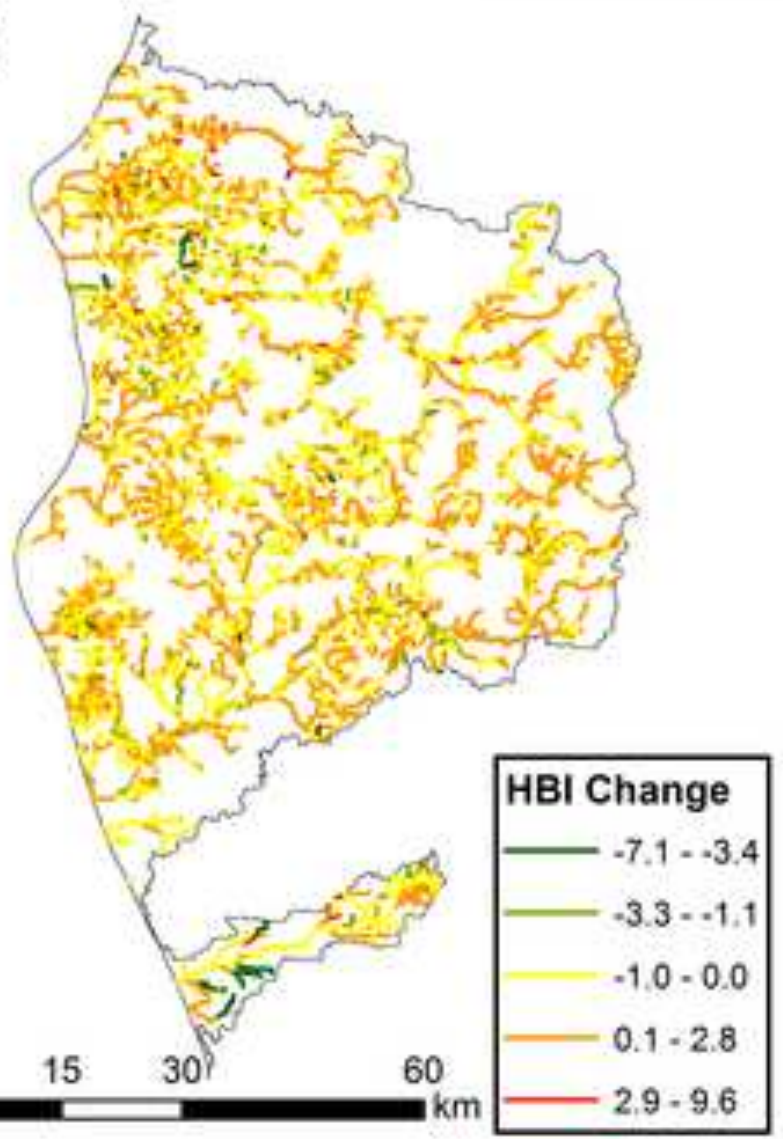

(b)

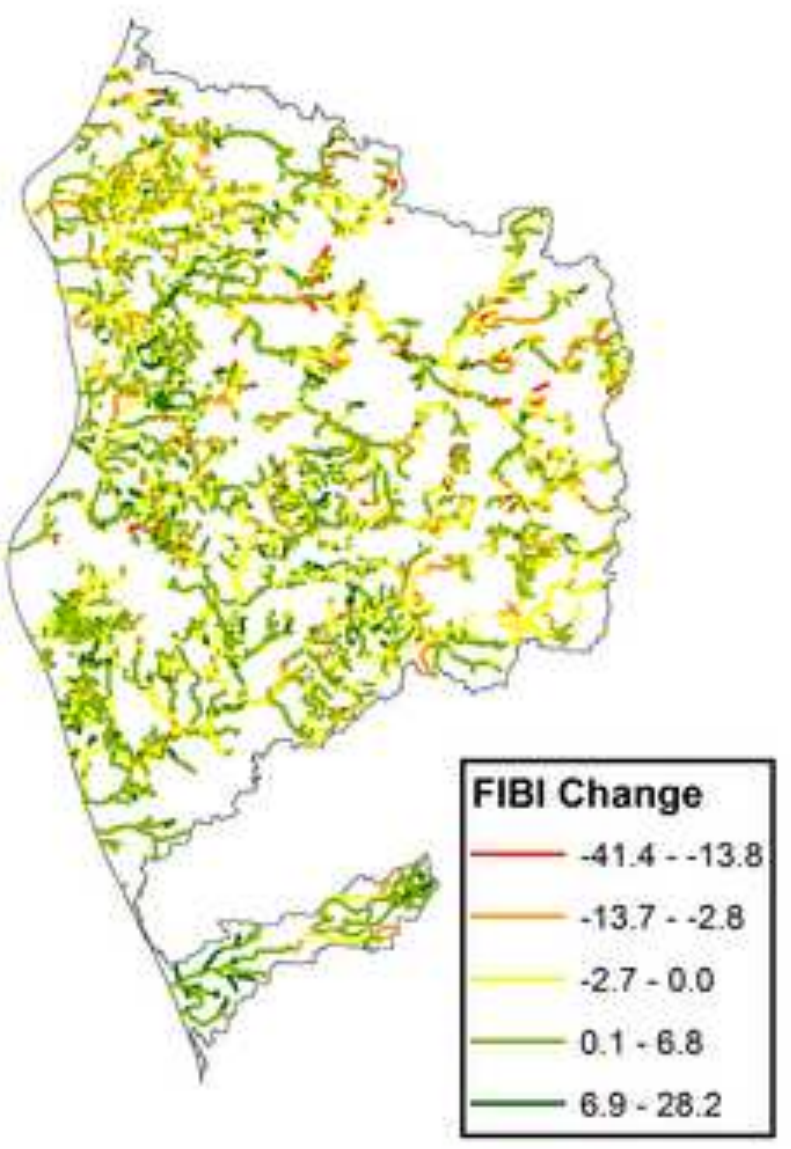

(d)

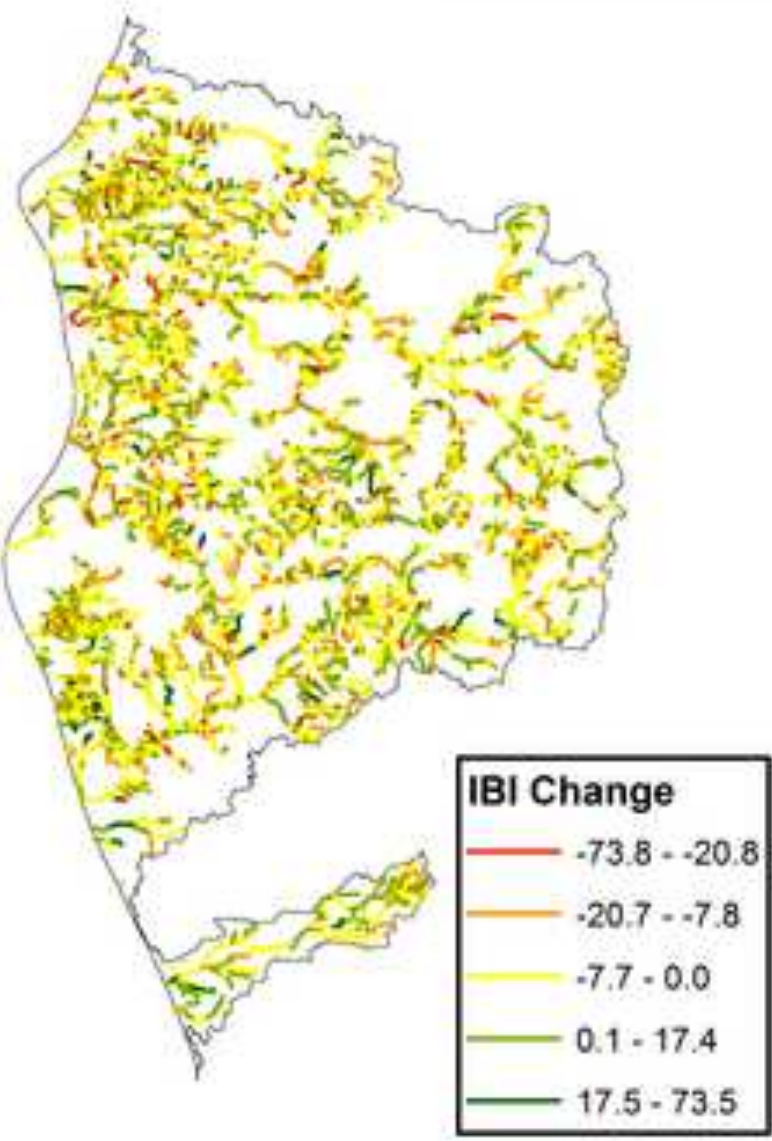


(a)

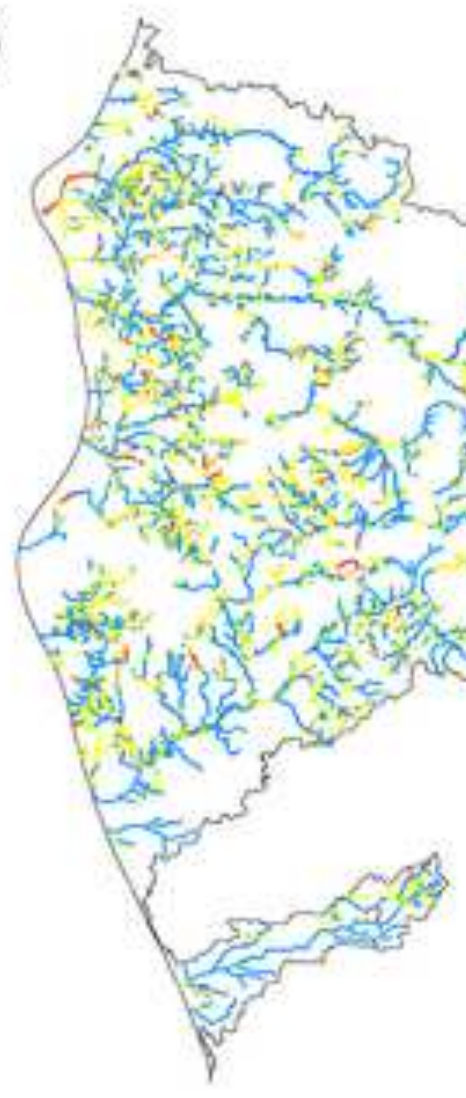

(b)

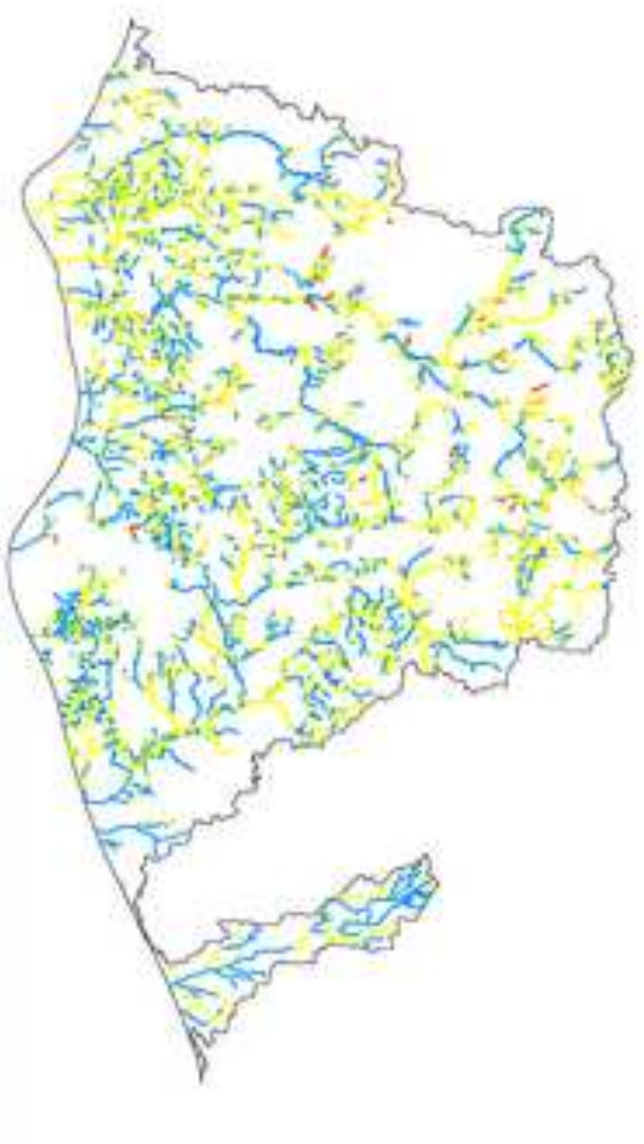

(c)

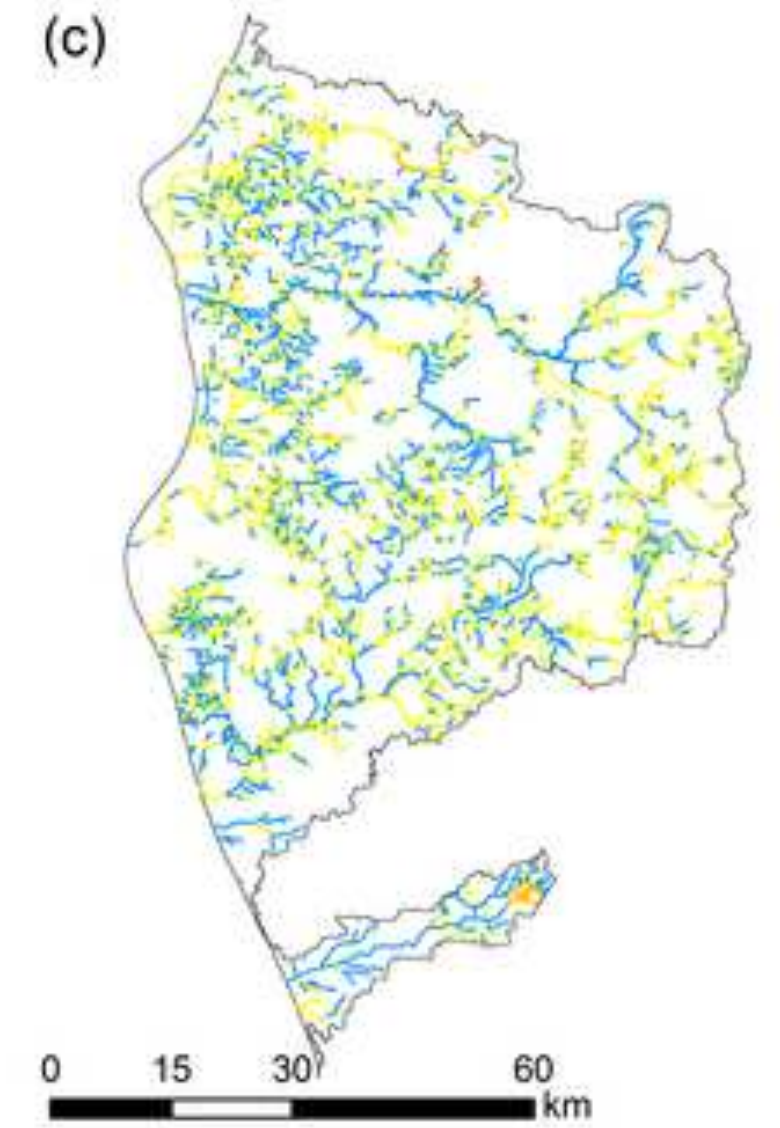

(d)
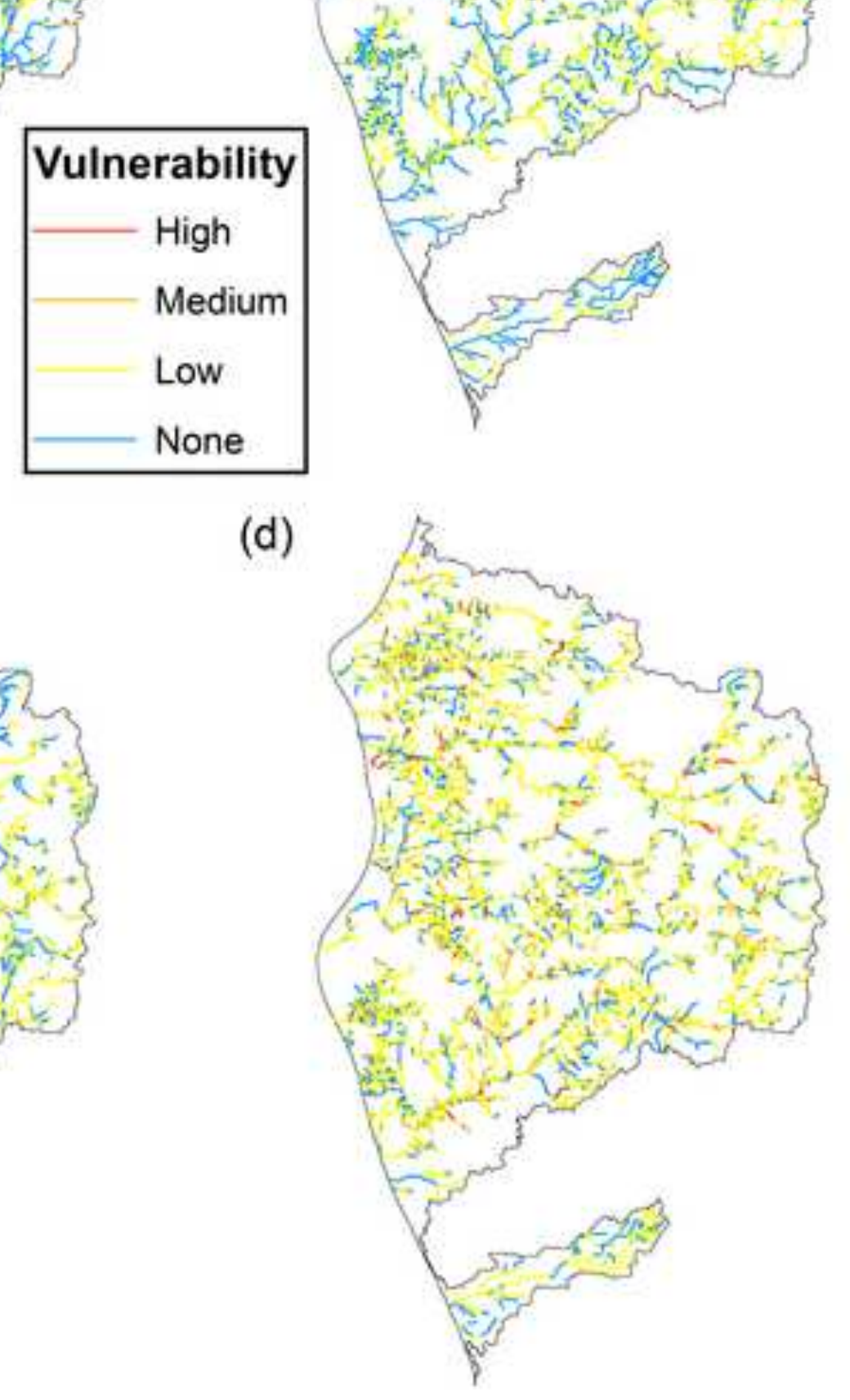

(d) 
Table 1. Characteristics of Michigan stream thermal classes

\begin{tabular}{lrll}
\hline Thermal Class & Temperature & Biotic community & Study Watersheds \\
\hline Cold & $\leq 17.5^{\circ} \mathrm{C}$ & $\begin{array}{l}\text { Coldwater } \\
\text { Cold-transitional }\end{array}$ & $\begin{array}{l}\text { Boardman-Charlevoix; Au Sable; } \\
\text { Muskegon; Pere Marquette-White }\end{array}$ \\
Cool & $17.5-19.5^{\circ} \mathrm{C}$ & $\begin{array}{l}\text { Coldwater, some } \\
\text { warmwater }\end{array}$ & $\begin{array}{l}\text { Au Sable; Pere Marquette-White } \\
\text { Boardman-Charlevoix; Cedar-Ford; }\end{array}$ \\
Warm & $>21.0^{\circ} \mathrm{C}$ & $\begin{array}{l}\text { Warmwater, some } \\
\text { coldwater }\end{array}$ & $\begin{array}{l}\text { Flint; Muskegon; Pere Marquette- } \\
\text { White; Raisin } \\
\text { Cedar-Ford; Flint; Raisin }\end{array}$ \\
\hline
\end{tabular}


Table 2. Variable selection results for each stream health model and temperature class, adapted from Woznicki (2015)

\begin{tabular}{|c|c|c|c|c|c|c|c|c|c|c|c|c|c|c|c|c|}
\hline & \multicolumn{4}{|c|}{ EPT } & \multicolumn{4}{|c|}{ FIBI } & \multicolumn{4}{|c|}{ HBI } & \multicolumn{4}{|c|}{ IBI } \\
\hline 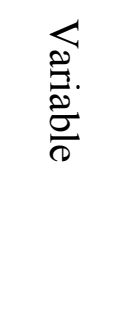 & $\frac{\varrho}{2}$ & 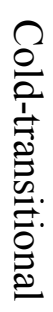 & 8 & & $\frac{\delta}{2}$ & 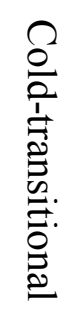 & 8 & 齐 & $\frac{\varrho}{2}$ & $\begin{array}{l}\Omega \\
\frac{0}{2} \\
\frac{1}{0} \\
0 \\
0 \\
0 \\
0 \\
0 \\
0\end{array}$ & 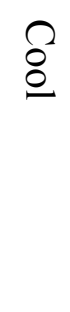 & $\begin{array}{l}\vdots \\
\text { : }\end{array}$ & $\frac{\varrho}{2}$ & 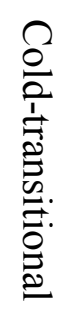 & 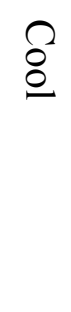 & 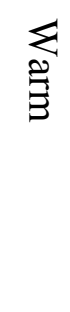 \\
\hline $\begin{array}{l}\text { DH6 } \\
\text { DH15 } \\
\text { DH18 } \\
\text { DH20 } \\
\text { DH22 }\end{array}$ & & X & & & & & & & $X$ & & $X$ & & & & $X$ & $X$ \\
\hline $\begin{array}{l}\text { DL9 } \\
\text { DL15 } \\
\text { DL16 } \\
\text { DL17 }\end{array}$ & & & $X$ & & & & & $\begin{array}{l}X \\
X \\
\end{array}$ & & & X & & & & & \\
\hline FH2 & & & & $X$ & & & & & & & & $X$ & & & & \\
\hline $\begin{array}{l}\text { MA25 } \\
\text { MA27 } \\
\text { MA31 } \\
\text { MA37 } \\
\text { MA40 }\end{array}$ & $X$ & & $X$ & X & & $X$ & $X$ & & $X$ & & & $X$ & & & & \\
\hline $\begin{array}{l}\text { MH15 } \\
\text { MH18 } \\
\text { MH19 } \\
\text { MH24 } \\
\text { MH27 }\end{array}$ & & $X$ & & $X$ & & & & & $X$ & $\mathrm{X}$ & & & & X & & \\
\hline $\begin{array}{l}\text { RA5 } \\
\text { RA7 } \\
\text { RA8 } \\
\text { RA9 }\end{array}$ & & & & & X & $X$ & & $X$ & & & & & & $X$ & & \\
\hline $\begin{array}{l}\text { TA1 } \\
\text { TA2 }\end{array}$ & $\begin{array}{l}X \\
X\end{array}$ & & & & $\begin{array}{l}X \\
X\end{array}$ & & X & & & & & & & & $\begin{array}{l}X \\
X\end{array}$ & $\begin{array}{l}\mathrm{X} \\
\mathrm{X}\end{array}$ \\
\hline TH3 & & $X$ & & & & $\bar{X}$ & $\mathrm{X}$ & & & X & & & & & & \\
\hline $\begin{array}{l}\text { TL1 } \\
\text { TL2 } \\
\text { TL3 }\end{array}$ & & & & & & & & & & & & & $\begin{array}{l}X \\
X \\
X\end{array}$ & & & \\
\hline
\end{tabular}

*See abbreviations section for complete variable definitions 
Table 3. CMIP5 multi-model ensemble dataset

\begin{tabular}{|c|c|c|}
\hline $\begin{array}{l}\text { Modeling Center } \\
\text { (or Group) }\end{array}$ & Institution & Model(s) \\
\hline FIO & The First Institute of Oceanography, SOA, China & FIO-ESM \\
\hline IPSL & Institut Pierre-Simon Laplace & $\begin{array}{l}\text { IPSL-CM5A-LR } \\
\text { IPSL-CM5A-MR }\end{array}$ \\
\hline MIROC & $\begin{array}{l}\text { Japan Agency for Marine-Earth Science and } \\
\text { Technology, Atmosphere and Ocean Research Institute } \\
\text { (The University of Tokyo), and National Institute for } \\
\text { Environmental Studies }\end{array}$ & $\begin{array}{l}\text { MIROC-ESM } \\
\text { MIROC-ESM- } \\
\text { CHEM }\end{array}$ \\
\hline MIROC & $\begin{array}{l}\text { Atmosphere and Ocean Research Institute (The } \\
\text { University of Tokyo), National Institute for } \\
\text { Environmental Studies, and Japan Agency for Marine- } \\
\text { Earth Science and Technology }\end{array}$ & MIROC5 \\
\hline MOHC & Met Office Hadley Centre & HadGEM2-ES \\
\hline MRI & Meteorological Research Institute & MRI-CGCM3 \\
\hline NASA GISS & NASA Goddard Institute for Space Studies & $\begin{array}{l}\text { GISS-E2-H } \\
\text { GISS-E2-R }\end{array}$ \\
\hline NCAR & National Center for Atmospheric Research & CCSM4 \\
\hline NIMR/KMA & $\begin{array}{l}\text { National Institute of Meteorological Research/Korea } \\
\text { Meteorological Administration }\end{array}$ & HadGEM2-AO \\
\hline NOAA GFDL & NOAA Geophysical Fluid Dynamics Laboratory & $\begin{array}{l}\text { GFDL-CM3 } \\
\text { GFDL-ESM2G } \\
\text { GFDL-ESM2M }\end{array}$ \\
\hline NSF-DOE-NCAR & $\begin{array}{l}\text { Community Earth System Model Contributors: } \\
\text { National Science Foundation, Department of Energy, } \\
\text { National Center for Atmospheric Research }\end{array}$ & CESM1-CAM5 \\
\hline
\end{tabular}

